Fecha de entrega: 24 de noviembre de 2008

Fecha de aprobación: 8 de abril de 2009

\title{
PRINCIPALES ETAPAS Y RASGOS DE LA FILOSOFÍA EN CUBA
}

\author{
MAIN STAGES AND FEATURES OF THE PHILOSOPHY IN CUBA
}

\author{
Pablo Guadarrama González ${ }^{1}$
}

\section{Resumen}

Este texto expone de forma ordenada y sintética los hitos de la filosofía en Cuba. El recorrido inicia con la producción filosófica de la escolástica, la recepción y respuesta, la formación del estudiantado, la creación de escuelas y la universidad como centro privilegiado de la producción textual en filosofía. Movimientos y corrientes como la Ilustración, el Humanismo, entre otros, generan discusiones al interior de las escuelas. Luego, la elaboración filosófica va siendo alimentada por un tipo de pensadores que incursionan en temas universales y generan una clase de escuela más especializada. El recorrido que aquí se presenta es cronológico, de tal forma que evidencia los pasos fuertes del pensamiento filosófico en la Isla.

\section{Palabras clave}

Filosofía cubana, filosofía, ilustración, humanismo, ateísmo, fideísmo, marxismo, leninismo.

\begin{abstract}
This text deals synthetically with the main hits of philosophy in Cuba. The route begins with the philosophical production of the scholastic, the reception and response, the education of the students, the creation of schools and the university as a privileged center for the production of philosophy. Movements and trends as the Enlightenment, humanism, among others, generate discussion inside the schools. Then, the philosophical production is fed by a type of thinkers that make their way into universal themes and generate a more specialized type of school. The route here presented is cronological, so that it makes clear the different stages of the philosophical thinking in the island.
\end{abstract}

$1 \quad$ Universidad de las Villas "Martha Abreu”, Santa Clara, Cuba. 


\section{Key words}

Philosophy, Enlightenment, humanism, atheism, fideism, marxism, leninism.

En Cuba, como en el resto de las islas caribeñas, no se constituyeron culturas de alto grado de desarrollo como la Maya, la Inca o la Azteca las cuales alcanzaron niveles tan elevados y complejos en todos los órdenes de la vida material y espiritual que permite debatir hoy, con mayor o menor razón, la existencia de ideas filosóficas antes de la llegada de los conquistadores europeos.

Por tal razón, los estudios sobre la evolución de la filosofía en Cuba durante los tres primeros siglos coloniales son aún muy limitados por las dificultades que se presentan con sus fuentes, no cabe duda que durante la primera etapa del devenir de la filosofía en este país, fue la escolástica contrarreformista española en sus diversas manifestaciones prácticamente la única que se cultivó en las instituciones religiosas, así como en la Real y Pontificia Universidad de San Jerónimo de La Habana -fundada en 1728-hasta las primeras décadas del siglo XIX (véase: Borge, 1990).

La filosofía escolástica, tanto en Cuba, como en otras partes, se caracterizaba por subordinar la razón a la fe cristiana y, por tanto, la filosofía a la teología, de tal manera que su postura teocéntrica no permitía el libre desarrollo del pensamiento lógico y científico. Se reducía a reproducir dogmáticamente las interpretaciones idealistas que en lo esencial Tomás de Aquino había elaborado de la controvertida filosofía de Aristóteles tratando de argumentar la existencia de Dios y la jerarquización, tanto de la naturaleza como de la sociedad a un orden divino preestablecido en el cual la Iglesia Católica gozaba de un privilegiado lugar. La escolástica, frenó la libre creación intelectual y convertía la filosofía en mera retórica cargada de artificios discursivos para justificar el poder eclesiás- tico. En el plano político y social trataba de eternizar el poder monárquico y feudal que ya comenzaba a resquebrajarse desde la irrupción del humanismo renacentista con el auge de la filosofía moderna e ilustrada y, en particular, del racionalismo y el empirismo que sobreponían el valor de la experiencia y la razón a la fe.

Pero la isla mayor de las Antillas, desde su entrada en la modernidad no estuvo aislada de las corrientes filosóficas e ideológicas que circulaban en el mundo. Desde el siglo XVI Cuba había sido punto necesario de tránsito entre la península y el continente americano, no sólo de soldados y mercancías, sino también de libros, sacerdotes -fundamentalmente dominicos y jesuitas ${ }^{2}$ - funcionarios y profesionales que de algún modo contribuyeron a la divulgación de gran parte de la producción filosófica elaborada por la humanidad hasta entonces.

Así, la polémica sobre la condición humana de los aborígenes americanos, de eminente raigambre filosófica, que tomó fuerza tanto en la Península como en algunas partes de este continente es de suponer que debió haber tenido alguna repercusión en las islas caribeñas donde la población autóctona había sido virtualmente aniquilada. Sin embargo, las fuentes documentales para fundamentar esta tesis son aún insuficientes.

Durante los siglos XVI y XVII Cuba no contó con una universidad, pero sí con varios

2 "Ya a fines del siglo XVII la situación se había vuelto favorable a los jesuitas, pues -a menos en la Nueva España, de donde irradiaba hacia el Caribe la autoridad política, financiera y religiosa- la compañía había logrado dominar la educación superior" (Goodgall, 1991, p. 26). 
colegios religiosos de las distintas órdenes, como el de San Juan de Letrán, en los que la filosofía se cultivaba (Guadarrama, 1996, p. 124). También en algunas de las otras villas como Santiago de Cuba, Bayazo y Puerto Príncipe existen testimonios de que era objeto de estudio de seminaristas y sacerdotes (Bachiller \& Morales, 1936, p. 95).

Los seminarios religiosos de San Carlos en La Habana y San Basilio el Magno en Santiago de Cuba, así como la Universidad de La Habana, constituyeron los centros principales en los que la escolástica desplegó su hegemonía (véase: Arce, 1996, pp. 41; 165). Del seno del primero surgieron los sacerdotes José Agustín Caballero y Félix Varela, encargados de la superación de la escolástica con la introducción del pensamiento moderno emancipatorio en múltiples sentidos, pues como ha planteado Leopoldo Zea (1965, pp. 154-155): “los pensadores cubanos saben, o han aprendido, lo insuficiente que es la pura emancipación política. Esta, si ha de ser realmente valiosa, no ha de verse sino en función de una emancipación más plena, la mental”.

Esta nueva etapa de la filosofía en Cuba se caracteriza por cultivar las ideas de la Ilustración acorde con las transformaciones socioeconómicas que se produjeron en la Isla, especialmente en la industria azucarera, desde la última década del siglo XVIII y como expresión también de los cambios de la política colonial propiciadora de un despotismo ilustrado ante la posibilidad inminente de las luchas independentistas de los pueblos latinoamericanos.

Las transformaciones que se fueron operando a raíz de las revoluciones burguesas en Europa, y en especial en Francia, incidieron recíprocamente en el impulso a la filosofía moderna que a su vez las había ideológicamente alimentando. El impulso de las investigaciones científicas y de la filosofía sobre bases seculares estimuló el auge de concepciones materialistas, sensualistas, experimentales, dialécticas, así como el cultivo de la tolerancia, la subjetividad, la individualidad y en el plano político de los derechos civiles, la igualdad, la libertad, la fraternidad, la ciudadanía, el cosmopolitismo, la democracia, etc., ideas que encontrarían favorable acogida en los ilustrados cubanos. Entre ellos José Agustín Caballero quien había permanecido en gran medida atrapado en las redes de la escolástica, de la que autocríticamente se emancipó y llegó a declarar:

Yo fui en primeros años de esta secta [se refiere a los escolásticos], y la amaba tiernamente; más la recomendé y enseñé a mis discípulos. ¡Qué vanidad no tenía del poder de mi entendimiento! ¡Cómo resolvía todo el universo y lo sujetaba al discurso! ¡Experiencia! Lo mismo era oírla nombrar que cerraba y apretaba los ojos hasta arrugarlos. Pero los abrí al fin, y la vi con tiempo; me avergoncé mucho de no haberla visto antes. Deserté de las banderas del engaño, y pasé a las de la verdad (Caballero, 1956, p. 133).

Fue el propulsor del pensamiento ilustrado y de una nueva concepción del hombre en la Isla, a fines del siglo XVIII ${ }^{3}$, al dar el paso decisivo para que la problemática filosófica alcanzase la autonomía necesaria como reflexión en relación con la teología.

Las reflexiones filosóficas de José Agustín no permanecieron enclaustradas en la docencia del Seminario de San Carlos. Trascendieron

3 "Su acción filosófica y pedagógica estuvo estrechamente relacionada entre sí, y tuvieron por objeto servir a la formación de un hombre ilustrado, de amplios conocimientos y de superior estatura moral [...] El inicio de la ilustración filosófica cubana: José Agustín Caballero" (Gerstenberg, 1985, p. 138). 
a la opinión pública a través del Papel periódico de la Habana, y muy especialmente, en su intento de presentación de un proyecto político reformista de transformación del poder colonial español ${ }^{4}$. Este vínculo orgánico de la actividad filosófica con la praxis social y especialmente política se convertiría en rasgo común predominante en el pensamiento cubano y latinoamericano de los dos últimos siglos.

En las polémicas que desarrolló José Agustín con la escolástica, hasta ese momento dominante en la isla, se expresó la lucha entre las ideas progresistas y las ideas retrógradas en la filosofía cubana de esa época. Su interés se centró básicamente en la perspectiva metodológica, a tono con las polémicas que se desarrollaban por entonces en el pensamiento moderno.

Asumió una postura crítica ante toda la producción filosófica existente hasta ese momento, sin caer en posiciones nihilistas, sino, por el contrario, asumiéndola dialécticamente, es decir, asimilándola y tratando de superarla. En tal sentido sostenía que "es más conveniente al filósofo, incluso al cristiano, seguir varias escuelas a voluntad, que elegir una sola a que escribirse" (Caballero, 1944, p. 209). De tal manera, se consideraba consecuente con las ideas de Tomás de Aquino, que había inducido a tomar esa actitud receptiva ante otras posturas filosóficas, cosa que al parecer no fue muy tomada en consideración por los que se proclamaban sus seguidores más inquisitivos. José Agustín, en cambio, recomendaba "cuanto nos conviene seleccionar de todos los filósofos, incluso de los paganos" (Caballero, 1944, p. 211).

4 "Porque el prócer quiso reformar la enseñanza y su plan era orgánico; se propuso adoctrinar, aunque con prudencia de ortodoxo, en teorías filosóficas modernas; y como pensador político, ideó todo un proyecto que alteraba el status colonial" (Vitier, 1970, p. 337).
Ese sería el espíritu electivo del cual estaría impregnada toda su obra.

En la búsqueda de las vías para la eliminación de los obstáculos, que de una forma u otra enajenaban al hombre, José Agustín se apoyó mucho en el empirismo de Francis Bacón. A la vez planteó los posibles errores a que puede conducir el sensualismo, y en ese aspecto fue decisiva la huella del racionalismo de Renato Descartes.

Como filósofo conciente de la necesidad de introducir los nuevos métodos propuestos por la filosofía moderna europea, a partir de las vertientes del experimentalismo baconiano y el racionalismo cartesiano, introdujo en el pensamiento cubano el electivismo filosófico como única posibilidad de romper los esquemas impuestos por el pensamiento escolástico (Busch, 2001, p. 136).

Ese método electivista ya había sido cultivado desde mediados del siglo XVIII entre algunos ilustrados mexicanos como Benito Díaz de Gamarra, Francisco Javier Clavijero y Francisco Javier Alegre quienes tuvieron cierta influencia en el ambiente filosófico cubano.

Se destacó en José Agustín la preocupación por reivindicar el lugar de la filosofía y su significado como enriquecimiento espiritual de la vida del hombre.

La filosofía es necesaria -sostenía- con necesidad de medio para completar la perfección natural del hombre [...] El hombre, para ser perfectamente completo en el orden natural, debe adornar su entendimiento con verdades y su voluntad de buenas costumbres; pero el hombre no puede lograr esto de manera cabal sin la filosofía, que distingue 
la verdad de la mentira y lo bueno de lo malo [...] (Busch, 2001, p. 201).

Para él, el hombre necesita ser completado con el conocimiento y para ese fin la filosofía es la vía más idónea, por cuanto ella "constituye una de las mayores perfecciones del espíritu humano" (Busch, 2001, p. 185). No se puede ignorar que en definitiva sus concepciones antropológicas coincidían con la visión naturalizada que existía por entonces del hombre. Según ésta, desde Aristóteles se veía a éste como un animal político, que aún era prevaleciente en la filosofía de la Ilustración y que Marx, en sus conocidas tesis sobre Feuerbach, criticaría posteriormente por su carácter extraordinariamente limitado para comprender la verdadera esencia humana.

Resulta interesante que un sacerdote, que en ningún momento puso en entredicho el lugar de la religión o de la teología -al contrario, para él la filosofía en última instancia era útil a la religión (Busch, 2001, p. 205)- insistiese tanto en la función enriquecedora de la condición humana que cumplía la filosofía, especialmente en relación con las virtudes ciudadanas. La atención que José Agustín le otorga a la filosofía en su vínculo con el Estado (Busch, 2001, p. 203) constituye otro indicio de que su pensamiento se articulaba más con la modernidad, que con la época anterior, cuando el individuo quedaba aplastado por fuerzas tan enajenantes como la arbitrariedad del despotismo feudal. La obra filosófica de José Agustín Caballero tuvo también trascendencia en el plano político-social, pero dejo una huella en cuanto al nexo que a partir de ese momento se reconoció como imprescindible entre la filosofía y las ciencias naturales, especialmente la física ${ }^{5}$.

$5 \quad$ Oleg Ternevoi (1981, pp. 89-90) sostiene que "Caballero quebró la confianza en la vieja metafísica y elevó la filosofía y la ciencia de su época. Fue el primero que investigó los fundamentos de la interrelación entre filosofía
Por su parte para Félix Varela la filosofía era como la puerta de entrada de todas las ciencias y, por tanto, mantenía un estrecho contacto con todas ellas. Fue él quien radicalizó el pensamiento filosófico cubano al ofrecerle una decisiva batida a la escolástica y simultáneamente sembrar la idea de la independencia política de la isla. Con su obra la filosofía en Cuba se articula definitivamente con el pensamiento moderno y bajo la influencia de Locke, Condillac, Descartes y Destutt de Tracy se opuso resueltamente al dogma escolástico de la supremacía de la fe sobre la razón.

El eje principal de la filosofía vareliana es la teoría del conocimiento por lo que planteaba su estudio con la misma objetividad que otro científico particular lo hacía en otra esfera. Para él, al proceso del conocimiento le eran aplicables los mismos métodos de otras ciencias como el análisis y la experimentación. Esa era la única vía que consideraba prudente para superar la antigua metafísica que aún dejaba sus secuelas significativamente en el pensamiento moderno, como se revela al plantear:

Concluyo, pues, que los filósofos hablan de propagaciones al cerebro, de impresiones en este órgano de vestigios, de espíritus animales, de alteraciones de fibras, y de otras cosas semejantes, sin tener la más ligera idea de ellas, ni haber comprobado su existencia con experimentos, ni observación alguna que merezca el más ligero precio. Unas densas tinieblas producidas por la más antigua metafísica envuelven, aún en nuestros días, esta parte de

y ciencias concretas, preparando así el terreno para el establecimiento de una firme alianza entre ellas en Cuba". 
los conocimientos humanos (Varela, 1961, p. 199).

Sostuvo una firme postura sensualista materialista en su gnoseología, que le hizo superar muchas de las limitaciones del racionalismo cartesiano, que había recepcionado a través de sus maestros Juan Bernardo O' Gaban -introductor en Cuba del sensualismo de Condillac-y J. A. Caballero por lo que llegó a sostener que este último podía conducir a los mismos errores que el escolasticismo.

Varela reveló en mayor medida, que Francis Bacón en sus ídolos, los posibles obstáculos que se le presentan al conocimiento del hombre. Aceptaba que los sentidos nos pueden engañar, pero sostenía que mediante la comprobación recíproca se puede verificar la validez de la información; sin embargo, no llegó a una verdadera comprensión de la dimensión de la práctica en el proceso cognoscitivo. Rechazó la teoría cartesiana de las ideas innatas y especialmente los intentos de reestablecerla por Cousin. Apreció desde temprano el carácter perturbador y enajenante que traían consigo las novedosas ideas del eclecticismo y el espiritualismo, que a inicios del XIX se trataba de importar y que atentaban contra la adecuada comprensión del sensualismo que él concebía como nominalismo.

Confiaba mucho en el método experimental, por la modesta seguridad que le ofrecía sobre los conocimientos alcanzados, y de tal modo se opuso a cualquier forma de agnosticismo que limitara las potencialidades cognoscitivas del hombre. Su arraigada confianza en la ciencia lo hizo ir más allá de Locke y Condillac, de los cuales se nutrió con fuerza. Su condición de religioso le inducía a creer en los milagros y en los misterios de la fe, pero estas creencias en ningún momento debilitaron su optimismo gnoseológico, ni su idea sobre la libertad de acción humana. "La vista de Dios en el acto no impide que yo opere libremente" (Ternevoy, 1981, p. 154), dejando así diferenciados los planos en que lo divino no cercenaba la autodeterminación existencial del hombre.

Tal libertad la estima Varela sobremanera en el acto cognoscitivo, pues ofrece los elementos necesarios para tener confianza en los resultados de la actividad cognoscitiva humana. Partía del presupuesto de que "en los objetos que están al alcance de la razón, se percibe no sólo su existencia sino su modo y causa, o por lo menos se nota la posibilidad de conocerlos" (Ternevoy, 1981, p. 121). Y luego de delimitar el poder del conocimiento divino en relación con el humano, que puede penetrar en todas las esferas de la naturaleza para él creada.

De aquí resulta-planteaba- que nuestro entendimiento es enteramente libre en todas las ciencias naturales, y también lo es en investigar la existencia de los objetos que superar la razón antes de creerlos. Infiérase igualmente que cuando creemos dichos objetos, procedemos conforme a la razón, pues ella nos prueba primero la existencia, y después la certeza de dichos objetos, y por consiguiente la necesidad de creerlos. La razón, pues, sin salir de su esfera, nos conduce a otra superior, en que ella misma descansa, por haber conseguido su objeto que es la verdad (Ternevoy, 1981, p. 122).

Varela recalcó siempre el carácter objetivo de los conocimientos humanos al considerar el pensamiento en dependencia del orden de la naturaleza. Así sostenía la soberanía de la razón en el campo de la filosofía y las ciencias naturales en cuanto al conocimiento de la naturaleza. El naturalismo que predominó en su gnoseología le condujo a las posiciones del materialismo, independientemente del hecho 
de tratar de combinar el sensualismo con su fe religiosa, que le hacía admitir la dualidad del alma y el cuerpo. Sin embargo, al analizar la relación entre el objeto y el sujeto adoptó una línea materialista, a pesar de las concesiones al idealismo que, junto a Locke, hizo al admitir las llamadas "ideas secundarias" en el proceso cognoscitivo. Pero supo evadir el escollo del subjetivismo en que cayeron otros representantes del sensualismo. Era lógico que su concepción religiosa del mundo se fundamentase en una sólida posición idealista objetiva, pero esto no impidió que en el plano gnoseológico destilara en él el materialismo filosófico en algunas de sus expresiones.

Este hecho se correspondió con sus ideas científico naturales, en las cuales el cuadro mecánico-atomístico de Newton y Gassendi era aceptado en tanto que se enfrentaba a cualquier tipo de especulación abstracta como las monadas leibnizianas o las moléculas orgánicas de Buffon. Su optimismo epistemológico se revirtió en el plano de sus ideas sociales y políticas al fundamentar la posibilidad de una ética superior que se basase en el entendimiento humano. Isabel Monal sostiene acertadamente que "la ética y la filosofía social de Varela descansan sobre su teoría del conocimiento" (1974, p. 64), lo que da lugar a su "humanismo de base empirista” (Monal, 1974, p. 64). Aquí fueron evidentes las huellas de Rousseau, Helvecio y Bentham, fundamentalmente, en franca correspondencia con sus aspiraciones ideológicas de incorporar a Cuba a la modernidad burguesa.

Partía del criterio de que "todos los hombres tienen igual derecho, por la naturaleza, a nuestra consideración" (Varela, 1961, p. 259). Pero para que el hombre pueda ejercer adecuadamente su libertad tiene que saber dominar sus condiciones de existencia, es decir, debe ser un hombre culto. Ésta es en definitiva la concepción en la que se asienta su criterio sobre la interrelación entre justicia y verdad cuando sostiene:

[...] todo hombre debe procurar acercarse cuanto pueda a lo más cierto y a lo más justo; y por consiguiente, como la opinión más probable es la que más se acerca a su sentir, a la verdad y justicia, se infiere que deba arreglarse a ella si es que ingenuamente desea proceder bien (Varela, 1961, p. 253).

Toda su labor pedagógica, de estimulación de las ideas científicas, ilustradas y humanistas en Cuba, estaba dirigida a crear las condiciones necesarias para que el pueblo cubano tomase mayor conciencia de su libertad y se diera a la tarea de realizarla con mayor plenitud.

Sus ideas éticas, apoyadas en su sensualismo materialista, por un lado, y su fe cristiana, por el otro, estimulaban en el hombre la búsqueda de la felicidad material y espiritual simultáneamente. El humanismo vareliano tenía una profunda raigambre utilitarista, porque se asentaba en la tesis de que: "El hombre naturalmente ama todo lo que se le asemeja porque se ama a sí mismo" (Varela, 1961, p. 231). Este ideario ético y pedagógico se asentaba en un sólido humanismo que, teniendo una raíz profundamente religiosa, le distanciaba significativamente de la tradicional postura de la Iglesia, expresada hasta entonces por la escolástica, respecto a la capacidad y poderío humanos.

El corte empirista de su ética le inducía, bajo la influencia de Bentham, a buscar en la utilidad el fundamento de la conducta humana, al considerar como útil aquello que se aviniese a la naturaleza humana y tuviese la aprobación de la razón. Su labor filosófica alcanzó el cenit en la obra concientizadora de aquella generación que seguía sus enseñanzas y donde los 
más profundos problemas políticos quedaban claramente expresados en lo pedagógico. De ahí que el tema del patriotismo ocupase un lugar central en su pensamiento, indicando en qué medida contribuía al proceso de toma de conciencia respecto a las exigencias del momento. Sobre la base del optimismo ético y social, se asentó su ideario revolucionario y la activa labor en pro de la independencia de Cuba, que lo obligó al exilio, como a otros ilustrados latinoamericanos.

Varela fue el primero que -dada su profunda confianza en el protagonismo del pueblo ${ }^{6}$ enseñó a pensar a los cubanos con cabeza propia - por lo que es deber de todo cubano profundizar en el conocimiento de su obra ${ }^{7}$-, pero no a pensar en abstracto, sino en la forma más concreta de realizar las ideas humanistas que en aquellas condiciones presuponía el logro inmediato de la independencia de España y el logro de una sociedad más justa y democrática.

Si se fuera a sintetizar - plantea Eduardo Torres-Cuevas- cuáles son los dos objetivos centrales de la filosofía de Varela habría que señalar que uno es encontrar el método para el conocimiento humano; el otro hallar las respuestas adecuadas a la problemática social cubana. Es decir que la filosofía tiene una función cognoscitiva y una función social (Torres-Cuevas, 1995, p. 160).

6 "Varela se percató, como ningún otro pensador de su época, de las aptitudes que tenían las clases populares para superarse cultural e ideológicamente y desempeñar un papel en la historia, acorde con sus intereses" (Ibarra, 2004, p. 283).

7 Véase: Santana, 1982; Serpa, 1983; Miranda, 1984; Reyes, 1989; Memorias del Coloquio Internacional de la Habana, 1999.
Eso tal vez contribuye a explicar la unidad orgánica que se observa entre su praxis filosófica y su praxis política.

La ilustración cubana culmina su triada filosófica con José de la Luz y Caballero. Otras personalidades en las ciencias naturales, como Tomás Romay, Francisco de Arango y Parreño, o José Antonio Saco, quien sustituyó a Varela en la cátedra de filosofía ${ }^{8}$, contribuyeron notablemente también al enriquecimiento de la cultura cubana de la época y a cimentar las bases desalienadoras y emancipatorias que aquella sociedad demandaba, pero, sin duda, José de la Luz iluminó la conciencia cubana desde el pedestal de la filosofía y con ese fin se enfrentó a los intentos del eclecticismo trasnochado de los hermanos González del Valle que pretendían ocupar un lugar dominante en el ambiente intelectual del país.

Un hombre de la cultura filosófica de Luz, alimentada por los viajes, especialmente a Norteamérica y Europa, por la amistad con notables hombres de esas latitudes y por el manejo de las fuentes bibliográficas en sus lenguas originarias, pudo situarse al más alto nivel de la producción filosófica de la época y tener una mayor incidencia en las nuevas generaciones que se formaron bajo su magisterio.

El hecho de conocer con profundidad los avances del sensualismo, así como sus limitaciones, al igual que el racionalismo, le permitió una mejor comprensión de la filosofía clásica alemana y de su carácter extraño a las necesidades del contexto cultural cubano. Conocedor de Hegel, prefirió no darlo a conocer a la juventud cubana por lo nocivo que podía resultar aquel andamiaje filosófico. Continua-

8 "Saco tuvo una cultura enciclopédica, y si pudo sustituir al Padre Varela en la cátedra de Filosofía, se debió precisamente a los profundos conocimientos que tenía de las ciencias físicas" (Menocal, 1947, Tomo II, p. 216). 
dor de la tradición vareliana, en especial la sensualista, intenta superar sus limitaciones en lo que Sánchez de Bustamante (1981, p. 10) denomina su "empirio-racionalismo gnoseológico" y Zayra Rodríguez (1988, p. 123) su "sensualismo racional" desde una perspectiva mucho más materialista que la de sus antecesores.

Si bien las ideas filosóficas de José de la Luz parecen centrarse en la problemática epistemológica, especialmente en su polémica sobre el método con los eclécticos, no es menos cierto que su concepción del hombre constituye el sostén principal, en definitiva, de su gnoseología. El punto de partida consistió en considerar al hombre como el ser más difícil de conocer

[...] que los demás seres, primero, porque en él se hallan reunidas las propiedades de todos los cuerpos y las facultades de todos los de su género, con la añadidura de la racionalidad, que es un grano de anís para la cuestión; el microcosmos en miniatura, nada menos, y aun algo más (Luz \& Caballero, 1946, p. 76).

Además concebía al hombre como "el animal más educable o perfectible que ofrece la naturaleza" (Luz \& Caballero, 1981, p. 77), por lo que de acuerdo con ese criterio consideraba el logro de la perfección humana en todos los órdenes, pero en especial en el ético, como la tarea fundamental de la educación. Ésta debía ser el vehículo que pusiera al hombre no sólo en contacto con los avances de la ciencia y la técnica, sino con las mejores formas de gobierno y de organización social sobre la base de la experiencia de otros pueblos y el imprescindible ensayo propio.

Crítico de cualquier tipo de apriorismo y de sistemas metafísicos que le impusieran al hombre una camisa de fuerza para interactuar con el mundo, Luz inculcaba confianza para que las nuevas generaciones se plantearan tareas desalienadoras más audaces. "La ciencia, es verdad, debe saberlo todo, así los aciertos como los extravíos; pero es para explicarlo todo, no para admitirlo" (Luz \& Caballero, 1981, p. 90). Y en otro momento señalaba: "[...] el hombre que no sea capaz de formar su ciencia por sí mismo, esto es, de darse una cuenta exacta de sus conocimientos, no puede progresar en su estudio" (Luz y Caballero, 1981, p. 61). Esta idea no debe interpretarse unilateralmente como si exigiese que cada persona construyese a su antojo una ciencia aparte. Su insistencia estaba dirigida a fomentar la libre búsqueda, por cada quien, de las causas y leyes que operan en la naturaleza y la sociedad.

Luz le otorgaba, al igual que el resto de los ilustrados cubanos, una función marcadamente liberadora a la filosofía. "A la filosofía toca ser centinela de la moral, para impedir que la frágil humanidad sea dividida o contaminada por tan horribles plagas" (Luz y Caballero, 1981, p. 73). Esa dignificación de la filosofía fue propia del espíritu ilustrado, que trataba de superar por todos los medios la dependencia que anteriormente ésta había tenido respecto a la teología.

También era un signo de los aires humanistas e ilustrados, el cultivo de la tolerancia, y en ese sentido Luz fue un exponente, pero sin que esto significase el abandono del sustancial elemento patriótico que aspiraba constantemente a enaltecer. "El filósofo -aseguraba-, como que es tolerante, será cosmopolita; pero ante todo debe ser patriota" (Luz y Caballero, 1981, p. 72; 165). Y por supuesto que el concepto de patria que Luz manejaba, en plena antesala de las luchas por la independencia en Cuba y posterior a las del resto de los países latinoamericanos, no incluía a España. Para él, la libertad era "el alma del cuerpo social (y) [...] el fiat del mundo moral". Esto significaba que el componente emancipatorio 
era, a su juicio, consustancial a la condición humana y, por tanto, la única forma de realizarse la sociedad con plenitud era a través de la libertad. Y para que esta se realice lo más importante es que existan los hombres capaces de conquistarla y conservarla, por eso destacaba que: "Hombres más que instituciones suelen necesitar los pueblos para tener instituciones. Y cuando se necesitan, los echa al mundo la providencia" (Luz \& Caballero, 1981, p. 164).

A tono con las ideas dominantes, también en el humanismo ilustrado se encontraban las ideas de José de la Luz respecto al progreso constante de la humanidad, que concebía como un progreso hacia la libertad: "Así en el progreso, y en último análisis, hemos de venir a parar en la libertad para que medre todo buen germen y se aplique y ensanche hasta donde debe" (Luz \& Caballero, 1981, p. 161), en el cual la humanidad constantemente salía beneficiada por su perfeccionamiento. "Así como la naturaleza necesita de tiempo y cataclismos para desarrollarse y perfeccionarse, así la humanidad (¡duro es apuntarlo!). Ha de pasar por los mismos trámites para su elaboración y mejoramiento" (Luz \& Caballero, 1981, p. 163). Por supuesto que tales cataclismos sociales no son otros que las revoluciones.

Se ha criticado en ocasiones injustamente a de la Luz como un reformista en una época en que, de acuerdo con la marea ideológica de la Isla, el independentismo se iba imponiendo y se demostraba la inviabilidad del reformismo. Carlos Rafael Rodríguez resolvió la caracterización de este problema cuando sostuvo que:

$\mathrm{Ni}$ jefe revolucionario ni fuerza retrasante fue don José de la Luz. Inquietador de conciencias, ideólogo de los grupos burgueses, reformista en momentos en que el reformismo era una vía aceptable, aunque no la única. La resonancia política de su obra fue mayor de lo que él mismo había pensado al final de sus días. El sentido político de su entierro y los odios españoles que se acumularon sobre él nos lo están indicando (1984, p. 20).

José de la Luz comprendió muy bien que las revoluciones sociales constituían un proceso necesario que no se producía arbitrariamente ni por una voluntad aislada, sino como el producto necesario de circunstancias concretas que la demandaran:

De ahí también la necesidad de la oportunidad, y la imposibilidad de hacer revoluciones, si no existen hechos físicos o morales que el genio no puede crear. Ni Napoleón revolucionaría la Isla de Cuba en circunstancias ordinarias ni aun extraordinarias; pero que le ataquen sus propiedades, y entonces la ovejita diventa leone (Luz \& Caballero, 1981, p. 164).

El humanismo de José de la Luz y Caballero se expresó permanentemente a través de la fuerte carga ética que destila todo su pensamiento filosófico, y que sirvió de ejemplo e inspiración a las nuevas generaciones intelectuales cubanas. Él partía de la concepción dominante en la ilustración sobre la igualdad entre los hombres, pero con impresionante agudeza sostenía: "Ni somos tan iguales que nos confundamos, ni tan diversos que nos contrastemos" (Luz \& Caballero, 1981, p. 142). Por eso la igualdad la concebía como una forma de que la justicia se realizara. "Antes quisiera yo ver desplomadas, no diga las instituciones de los hombres, sino las estrellas todas del firmamento, que ver caer del pecho humano el sentimiento de la justicia, ese sol del mundo moral" (Luz \& Caballero, 1981, p. 136). 
Este fermento ético se mantendría latente no sólo en las nuevas generaciones filosóficas sino que trascendió por medio de la enseñanza hasta los más recientes revolucionarios, que han tratado con forzado éxito de viabilizar aquel cultivo de la dignidad humana a que aspiraba el pensamiento de José de la Luz y Caballero.

La identificación del progreso social con la moral consistió en uno de los ejes centrales de la filosofía de José de la Luz (véase: Gerstenberg, 1986). En tanto no hubiese las condiciones necesarias para el inicio de la emancipación política, cualquier avance en el enriquecimiento de la moral constituía incrementar un peldaño al ascendente proceso desalienador humano.

La obra filosófica de José de la Luz contribuyó notablemente al enriquecimiento de la vida espiritual y, en especial, de la filosofía en la sociedad cubana del siglo XIX. A la vez constituyó un elemento decisivo en la preparación ideológica de la "guerra necesaria" por la independencia de Cuba, hecho éste que se plasma evidentemente en la huella que dejó en las nuevas generaciones de intelectuales comprometidos entre los que se destacan, entre otros, Enrique José Varona, Manuel Sanguily y José Martí.

La ilustración cubana constituyó un esfuerzo propio por asimilar e integrar armónica y creativamente las más avanzadas conquistas, hasta su época de la filosofía moderna sobre el proceso del conocimiento, los avances de las ciencias naturales y sociales, especialmente, las ideas referidas a lograr las mejores formas de gobierno y de reestructuración socioeconómica de la sociedad.

La historia de las ideas filosóficas en Cuba comenzó su sistematización a mediados del siglo XIX con la labor de José Manuel Mestre en la que reflejaba el carácter que había tomado este aspecto de la cultura cubana.
Mestre deseaba enaltecerlo y criticar el indiferentismo que va poco a poco minando nuestra escasa vida intelectual. En su análisis se destacaba el culto al saber científico y a la experimentación, así como el sentido humanista que es propio a todo pensamiento ilustrado. Mientras tanto, en la Universidad de la Habana se mantenía, hasta casi finales del siglo XIX, anquilosada en el espíritu metafísico más trasnochado.

Los estudios sobre la influencia del eclecticismo, la filosofía clásica alemana en Cuba (Sánchez \& Montoro, 1984) -en particular Kant, promovido por José del Perojo, quien fue el primero que tradujo al español $L a$ crítica de la razón pura (véase: 2003), y Hegel, que encontró seguidores en José Silverio Jorrín, en Enrique Piñeiro, antes de su adhesión al positivismo (véase: Guadarrama, 1980, pp. 157-170) y Rafael Montoro (véase: Piñera, 1986)-, y el krausismo, que dejaría alguna huella en Antonio Bachiller y Morales (véase: Bachiller \& Morales, 1857) y en José Martí (Gómez, 1989, pp. 187-210), así como el neotomismo hoy reclaman una mayor profundización a fin de explicar las causas por las cuales estas corrientes en particular no tomaron tanta fuerza en la Isla en comparación con el positivismo.

Todas las manifestaciones de la vida científica, religiosa, artística, pedagógica, jurídica, política, moral y en especial filosófica latinoamericana de fines del siglo XIX (véase: Guadarrama, 2004) y la mayor parte de sus personalidades intelectuales más significativas, también en el caso de $\mathrm{Cuba}^{9}$ entre las que se destaca Enrique José Varona ${ }^{10}$ se vieron

9 Para mayor profundidad puede verse: Guadarrama, 1982, pp. 61-84; 1981, p. 117-136; 1981, pp. 37-70; 1979, pp. 155- 184.

10 Para mayor profundidad véase: Guadarrama, 1981, 2, B 1. 15 (204); 1985, pp. 60-87; Guadarrama, \& Tussel, 1986. 
afectadas de algún modo por el positivismo en su expresión sui generis.

El positivismo fue cultivando una filosofía optimista llena de confianza en el hombre, en la capacidad creativa de su pensamiento, en la cultura, en la ciencia, en el progreso y el desarrollo industrial. Aliado al liberalismo y a la defensa de la democracia burguesa sus ideas resultaban muy avanzadas.

Como afirmé en un texto anterior publicado en la Revista Historia de la Pedagogía Latinoamericana (2004, pp. 209-234): En Cuba y Puerto Rico, donde aún no se había logrado la independencia política, esas ideas tendrían mucha mayor significación y carácter progresista, al punto que incluso llegaron a ser consideradas como subversivas por el gobierno colonial español, dada su defensa de las libertades políticas exigidas por el orden democrático burgués. Así, en estas dos islas, la filosofía positivista contribuía a forjar la conciencia de la imprescindible autodeterminación para encaminarse hacia el progreso social.

En sentido general, esta filosofía desempeñó una función progresista en América Latina, pues sintetizaba las aspiraciones de la débil burguesía nacional que en esta región pretendía sustituir las caducas relaciones precapitalistas de producción, y estimular el desarrollo tecnológico e industrial como premisa indispensable para alcanzar en todos los planos, una verdadera independencia de los pueblos latinoamericanos.

Si algo tuvo de sui géneris el positivismo latinoamericano fue no identificarse con la tesis sobre el posible debilitamiento de la filosofía y prácticamente su disolución con el auge de las ciencias particulares. En todo momento, en los positivistas latinoamericanos se apreció su alta estimación por el saber filosófico, por lo que fundamentaron el carácter metodológico y de concepción general del mundo que acompaña siempre a la filosofía en correspondencia permanente con el desarrollo de las ciencias particulares, sin que este signifique un atentado contra su objeto de reflexión.

En Europa, en esa misma época, esta filosofía ya no desempeñaba una función tan progresista como puede apreciarse para Latinoamérica, pues los elementos idealistas subjetivos y agnósticos que la caracterizaban entorpecían el propio reconocimiento de los avances de la ciencia. Tales rasgos no caracterizaron tanto a los positivistas latinoamericanos, pues estos cultivaron mucho más los elementos materialistas, y de confianza en el poder de la ciencia y la tecnología, por lo que existieron estrechos vínculos entre los seguidores del positivismo y los del materialismo científico-natural de los llamados librepensadores (Véase: 1984, pp. 14-35 \& 2004, pp. 209-234).

El positivismo sui generis latinoamericano no significó una simple adaptación de una filosofía europea a estas latitudes, sino una incorporación y recepción creadora con profundos elementos originales, disímiles y renovadores, que constituyeron una forma específica de superación de dicha corriente en el ámbito particular de este continente, como expresión concreta del desarrollo de la lucha entre el materialismo y el idealismo filosófico.

El principal representante del positivismo en Cuba, y uno de los más destacados en toda América Latina, fue Enrique José Varona. Fue un filósofo que se mantuvo atento al desarrollo de las investigaciones científicas de su época, como se manifiesta en los múltiples artículos que publicó para comentar estos avances, tanto en las ciencias naturales como en las sociales. Su labor en ese plano resultó muy meritoria para el desarrollo de la cultura cubana de su época. 
Se percató del creciente papel que asumían las ciencias en el mundo moderno y, por tanto, la necesidad que tenían los pueblos emergentes de cultivarla para disfrutar de sus logros e intentar alcanzar el nivel de vida y desarrollo de los más avanzados. A su juicio:

La pesquisa de la ciencia ha de ser desinteresada; muy cierto; pero desinteresada no quiere decir indiferente. Ha de ser animarla y moverla el alto y claro propósito de que sus adquisiciones se encaminen al mejoramiento del hombre, al bien de la patria, al mejoramiento de la civilización; que es la manera que tienen los pueblos de contribuir con su cuota individual al progreso de la humanidad (Varona, 1918, p. 27).

Estimulaba la investigación científica porque sabía que el hombre, utilizando ese insustituible instrumento podía asegurarse una vida mejor.

El hombre necesita prever los cambios que se verifican en torno suyo y muchas veces necesita suscitarlos. Las relaciones de causa le permiten esa previsión y le dan ese poder... El fin de la ciencia es llegar al descubrimiento de las causas y las proporciones (Varona, 1902, p. 132).

Independientemente de que su concepción sobre la relación causal tuviese la misma limitación propia del fenomenalismo empirista de los positivistas, su intención de ir a la búsqueda de ellas desprejuiciadamente constituía un estímulo al desarrollo de la ciencia en el ambiente intelectual cubano. Las ideas de Varona respecto al papel de la ciencia no se limitaban a un enjuiciamiento de carácter teórico con fines exclusivamente académicos. Ellas estaban orientadas a ponerse en función de la transformación de la realidad social de su tiempo.

Algo que diferenció a Varona como a otros representantes del positivismo sui géneris latinoamericano, es no haber compartido la tesis común a esta corriente, según la cual el desarrollo de las ciencias atentaría contra el contenido y el status del saber filosófico. Para él esa era una premisa errónea.

De aquí -afirmaba- que al renacimiento de las ciencias naturales se pronosticara la desaparición de la filosofía. Conclusión por más precipitada. La filosofía no es justiciable de los desvaríos de los filósofos. En vano se le conmina a abandonar el campo. No puede desaparecer porque responde a una necesidad constitutiva de nuestro yo: la de poseer una síntesis general que explique más o menos completamente los dos mundos de la realidad, penetrando en lo posible en el enigma de su conjunción [...] El papel de la filosofía es preparar esa síntesis, llegar, si puede a la organización completa de los conocimientos. Y esto no puede confundirse con el papel de las ciencias particulares (Varona, 1906, p. 337).

Para él la filosofía tenía un objeto y una función que jamás podrían ser sustituidos por las ciencias, aun cuando no pudiese prescindir de los resultados de éstas, del mismo modo que las ciencias no podrían desarrollarse plenamente al margen del desarrollo del pensamiento filosófico. La labor integradora de todo el saber humano y la pretensión de esclarecer los enigmas planteados por enfoques dicotómicos de la realidad que conducían al dualismo, constituían para el pensador cubano una labor eminentemente filosófica que la ciencia no podría nunca por sí sola resolver. 
Varona continuó la preocupación básica que se había apreciado en la filosofía de la Ilustración cubana por el problema del método.

Mientras la lucha de las opiniones es cada día más encarnizada, el acuerdo en los métodos va siendo cada día un hecho más próximo a realizarse. Y es que por fin hemos llegado o nos aproximamos a la posesión de esta verdad, que parece rudimentaria: el espíritu humano podrá diversificar hasta lo infinito sus concepciones, pero en su modo de funcionar tiene que ser fundamentalmente idéntico. Ahora bien el conocimiento exacto de este su modo de funcionar nos ha de dar el método verdadero; y creo no pecar de temerario afirmando que la gran conquista filosófica de nuestro siglo es la posesión del método (Varona, 1880, p. 28).

Para Varona el método de conocimiento más adecuado era el que superaba el inductivismo y el deductivismo, es decir, el que lograba una unidad sintética de ambos. Según él: "En el método, señores, es donde está la unidad (se refiere de la inducción y la deducción PG); porque el método no es otra cosa que el espíritu humano aplicando sus actividades según sus leyes constitutivas" (Varona, 1880, p. 175).

Sin embargo, en su pensamiento se aprecia cierta tendencia más inclinada hacia el empirismo que hacia el racionalismo. Pues al parecer este último le recordaba más el aristotelismo y la escolástica, los cuales consideraba afortunadamente ya superados en la modernidad. Aunque, a su vez, insistía en reconocer las limitaciones de cualquier enfoque hiperbolizador del empirismo que no tomase en consideración el insustituible papel del pensamiento lógico. No en balde dedicó la primera parte de sus Conferencias filosóficas al estudio de la lógica.

Varona no fue un filósofo que se dejó atar por una postura ideológica cerrada o una corriente filosófica en particular. Simpatizó la mayor parte de su vida con el positivismo, pero también supo dejarlo a un lado y superarlo cuando comprendió sus limitaciones. Fue lo suficientemente capaz para analizar los problemas filosóficos y sociológicos con el mayor nivel de originalidad y autenticidad que sus circunstancias históricas se lo permitieron.

Su incansable avidez autodidacta por la lectura de los clásicos de la filosofía mundial, así como la realidad cubana y latinoamericana, sus estancias en España y Estados Unidos, le sirvieron de fuente directa de información y objeto permanente de análisis para enfoques con óptica propia. Su pensamiento no quedó encartonado en anaqueles académicos. Supo ganarse el merecido prestigio en el ámbito intelectual, especialmente en la vida filosófica, literaria y periodística de su época, y a la vez trascender en la praxis pedagógica y política de su época.

Algo que debe apuntarse significativamente en favor de nuestros positivistas como Enrique José Varona y Manuel Sanguily fue el culto que rindieron a los pensadores cubanos que los antecedieron. No se dejaron cautivar por la exclusiva xenofilia anglosajona, que el pensador uruguayo José Enrique Rodó caracterizó como nordomanía, y que fue propia de otros seguidores del positivismo en el continente.

Se sentían continuadores de una tradición de pensamiento nacional que de ningún modo contraponían arbitrariamente a la filosofía europea. En estos pensadores del siglo XIX cubano no se manifestaron complejos ni de inferioridad ni de superioridad respecto a la vida filosófica de otras latitudes. Sabían 
admirar lo que era digno de elogio en la cultura filosófica de otros pueblos, pero también eran fervientes admiradores de la producción filosófica nacional.

La expresión superior de la postura reivindicadora de los valores de la cultura y en especial del pensamiento de nuestra América ha sido, sin dudas, la obra de José Martí cuya raigambre filosófica en ocasiones ha sido subestimada o encasillada en escuelas y corrientes que limitan la comprensión de su especificidad. Afortunadamente, en los últimos años se han incrementado las investigaciones sobre la dimensión filosófica de su pensamiento ${ }^{11}$.

Tanto sus criterios sobre algunos de los representantes de la filosofía universal, como sus reflexiones más profundas sobre el pensamiento gestado en estas tierras, expresan el reconocimiento a la producción de ideas en general y, en especial, las filosóficas, de esta región. Su vocación emancipatoria se asentaba en la existencia de un inagotable manantial de recursos teóricos elaborados por manos propias, aun cuando muchos de sus ingredientes fuesen adquiridos en otros contextos culturales, como siempre ha sucedido en la historia de las ideas.

Las preocupaciones más metafísicas estuvieron presentes en distintos momentos de la vida de aquel profesor de filosofía en Guatemala, que fue José Martí. Ellas no obstaculizaron, por el contrario, facilitaron las proyecciones de su pensamiento volcado hacia las urgencias más concretas del hombre latinoamericano. Sus inquietudes sobre la correlación entre el ser y el pensar, el papel de la subjetividad humana así como otras preocupaciones de profundo carácter filosófico,

11 Véase: Martínez, 1990; Fornet-Betancourt, 1994; Jardines, 1990; Rodríguez de Lecea, 1995, pp. 101-108; Ronda, 1983, pp. 43-81; Escalona, 1987; Guadarrama, 2003. como son la cuestión de la naturaleza humana y la dimensión ética de la actividad del hombre, estuvieron muy presentes en toda la obra martiana no por simples razones académicas.

Martí se opuso a cualquier postura epistemológica que subestimase la capacidad creativa de la subjetividad humana o que se dejase arrastrar por ideas contemplativas sobre la concepción entre el sujeto y el objeto del conocimiento.

Debe tomar el hombre la Filosofía, no como el cristal frío que refleja las imágenes que cruzan ante él; sino como el animado seno en que palpita, como objeto inmediato $y$ presente, la posible acomodación de lo real de lo que el alma guarda como ideal anterior, posterior y perpetuo [...]. (1975, Tomo XIX p. 365).

Esto no significaba en modo alguno que asumiera una posición subjetivista sino que más bien tratara de encontrar un punto intermedio o de relación entre lo que él consideraba era el objetivismo del materialismo y el subjetivismo del idealismo.

Martí propugnaba una filosofía de la relación entre lo objetivo y lo subjetivo, entre el mundo físico y el espiritual, que supere tanto el materialismo contemplativo como un idealismo especulativo; por eso sostiene que:

Al estudio del mundo tangible se ha llamado física; y al estudio del mundo intangible, metafísica. La exageración de aquella escuela se llama materialismo; y corre con el nombre de espiritualismo, aunque no debe llamarse así, la exageración de la segunda. Todas las escuelas filosóficas pueden concretarse en estas dos. Aristóteles dio el medio científico que ha elevado tanto, 
dos veces ya en la gran historia del mundo, a la escuela física. Platón, y el divino Jesús, tuvieron el purísimo espíritu y fe en otra vida que hacen tan poética, durable, la escuela metafísica. Las dos unidas son la verdad: cada una aislada es sólo una parte de la verdad, que cae cuando no se ayuda de la otra (Martí, 1975, Tomo XIX, p. 361).

Esta posición martiana en nada constituye una expresión de eclecticismo, sino todo lo contrario. Es una muestra de la aguda observación del pensador cubano por no dejarse arrastrar por enfoques unilaterales del proceso del conocimiento. En ningún momento hay en Martí algún tipo de propensión subjetivista hiperbolizante o enfoque especulativo que desconozca la fuente nutritiva de todo saber filosófico, esto es, el conocimiento científico. Al contrario, para él la ciencia ocupaba un lugar relevante en la conformación de cualquier tipo de cosmovisión y por eso no podían ser subestimados sus alcances.

Tenemos que para conocer es necesario examinar: que la fuente más creíble de verdad es nuestro propio examen; que el examen es medio seguro de conocer la aplicación de nuestra aptitud de conocer a la cosa conocible: observación, y el pensamiento sobre lo observado: reflexión. Hay, pues, en Filosofía sujeto que conoce, y que, aislado, produce la Filosofía subjetiva alemana: objeto conocible, que, aislado, produce la Filosofía naturalista moderna, y medios de conocer. Dedúcese que la Filosofía debe estudiar al hombre que observa, medios con que observa y lo que observa: Filosofía interna, Filosofía externa y Filosofía de relación. Filosofía es la ciencia de las causas. Conocer las causas posibles, y usar los medios libres y correctos para investigar las no conocidas, es ser filósofo. Pensar constantemente con elementos de ciencia, nacidos de la observación, en todo lo que cae bajo el dominio de nuestra razón, y en su causa: he ahí los elementos para ser filósofo (Martí, 1975, Tomo XIX, p. 362).

Tal vez uno de los elementos que distanciaban a Martí del enfoque positivista precisamente esté relacionado con la búsqueda de las causas de los fenómenos, pues sabido es que el fenomenalismo positivista evadía de algún modo el conocimiento de las causas y favorecía la relación funcional. En fin, múltiples razones, tanto de carácter epistemológico como sociológico e ideológico distanciaban necesariamente a Martí del positivismo latinoamericano aún cuando este tuviese peculiaridades sui géneris que lo diferenciaban del europeo y que el pensador cubano supo admirar.

En tal sentido, Martí reconoce que el presupuesto positivista de tratar de buscar una explicación científica a la conducta humana, $y$, especialmente, demostrar la existencia de leyes del desarrollo social del mismo modo que existían en el mundo natural, como en aquellos momentos incursionaba la naciente psicología, podía contribuir notoriamente a un perfeccionamiento de la sociedad.

El pensamiento filosófico de Martí constituye una especie de intento sintetizador de todo lo mejor que se había consolidado y difundido en la producción filosófica universal hasta su época y por esa razón no podía de manera alguna subvalorar, entre otras, la filosofía positivista que predominaba el ambiente latinoamericano. Del mismo modo, tampoco fue indiferente ante las ideas filosóficas de otros grandes pensadores como Kant, Hegel, Marx, Emerson, etc., Martí, sabiamente, eligió la 
mejor opción de un hombre de su estirpe intelectual y humana, al situarse por encima de los patronímicos, gentilicios y ortodoxias en cuanto a corrientes filosóficas y hacer de las filosofias y no de una filosofía en particular el inagotable arsenal para la comprensión y transformación del mundo.

La filosofía en Cuba tuvo durante el siglo XIX un desarrollo extraordinario junto a otras manifestaciones de la cultura nacional, en el que se aprecia un marcado contenido humanista y una pretensión desalienadora orientada a promover al pueblo cubano hacia una emancipación que trascendiera a lo político y se instalara en el plano social y cultural. Por tal motivo sus principales cultivadores se caracterizaron por una intensa actividad política que trascendía el mundo académico a favor de la independencia, de la soberanía y las transformaciones sociales reclamadas por el pueblo cubano.

La mayor parte de sus representantes eran políglotas por lo que tenían rápido acceso a la producción filosófica internacional de su tiempo y por tal motivo mantuvieron un sorprendente nivel de actualización sobre temas, problemas y corrientes de esta disciplina en su época. Con frecuencia polemizaron e hicieron de la crítica un insustituible instrumento de desarrollo de la filosofía y de la cultura nacional.

Fueron también muy dados a hacer públicos sus análisis y debates más allá de los cerrados círculos intelectuales e hicieron muy buen uso de la prensa y de las publicaciones periódicas de amplio perfil para trascender a otros sectores populares con la peligrosa arma de las ideas racionales, con el poder de los argumentos y no el argumento del poder.

Los pensadores cubanos trataron de estar al tanto de los avances de las ciencias naturales y sociales de la época para romper con todos los obstáculos que impedían en Cuba y en
América Latina el despliegue de la modernidad. Y con ese objetivo se caracterizaron por mantener una vida intelectual con amplios intercambios internacionales de ideas, con múltiples personalidades de otros países.

Existen razones suficientes para que múltiples investigadores de diversos países hayan resaltado la alta talla intelectual de los principales representantes de la producción filosófica cubana culminante en el siglo XIX. El nacimiento de la república neocolonial a principios del siglo XX no implicó un cambio significativo de inmediato en la vida filosófica nacional, pues el positivismo de algún modo se mantendría aún latente por algún tiempo, si bien comenzaron a hacerse sentir la influencia del irracionalismo y el vitalismo que comenzaba a tomar fuerza en esa época, paulatinamente con la obra de Nietzsche, Bergson, Ortega y Gasset, entre otros.

Es indudable que cierto reflujo se había observado en el devenir de la filosofía en la Isla después de las célebres Conferencias filosóficas de Varona dedicadas a la lógica, la ética y la psicología. El propio filósofo menguó significativamente su producción académica en favor de la actividad política y literaria a principios del siglo XX. Algunos estudios indican que no desaparecieron del todo preocupaciones, pero sí es un hecho que la historia de las ideas en Cuba -como se observa en Sergio Cuevas Zequeira, quien sería uno de los continuadores de la labor de Varona en la Universidad de La Habana ${ }^{12}$, no ocupaba los primeros planos de la atención en la vida filosófica nacional.

Ello no significa que hubiese una carencia de labor filosófica como algunos han sostenido. Es cierto que la injerencia cultural norteamericana sobre la Isla se hizo sentir ya en esa

12 Como los efectuados por Sergio Cuevas Zequeira sobre la labor filosófica de Varona y Varela (1917 y 1923). 
época, pero eso no significó un predominio de las ideas filosóficas emanadas del poderoso vecino, especialmente el pragmatismo que encontró más críticos, como Cuevas Zequeira, que adeptos.

Cuevas Zequeira mantuvo activa la identificación de la tradición filosófica cubana por su preocupación en la cuestión del método, al favorecer el enfoque empirista y oponerse al dogmático deductivismo tomista-aristotélico que intentaba recuperarse de los embates sufridos por la filosofía ilustrada, primero, y después, por el positivismo.

Investigaciones sobre la filosofía en Cuba durante la primera mitad del siglo XX han demostrado la riqueza de la continuidad de la producción filosófica de este período con la anterior (véase: Guadarrama \& Rojas, comp. 1995/2003). Sin embargo, razones ideológicas promovieron una cierta indiferencia o descuido cómplice en relación con el pensamiento de José Martí, el cual durante las primeras décadas prácticamente no fue divulgado. Hubo que esperar a la década crítica de los años veinte para que se despertara la promoción de la conciencia nacional y junto al espíritu antiimperialista se produjera la revitalización de los estudios del pensamiento cubano. Fue ese el momento en que Julio Antonio Mella insistió en la necesidad de escribir un libro sobre Martí. Es también cuando Juan Marinello y Emilio Roig de Leuschenring definen su proyección rescatadora del pensamiento martiano. Del mismo modo que Carlos Rafael Rodríguez impulsó el análisis de otras personalidades y líneas del pensamiento cubano decimonónico (véase: Rodríguez, 1987, Tomo III).

Durante las dos primeras décadas se observa en el pensamiento filosófico cubano, el mantenimiento de la tradición materialista articulado con concepciones científico-naturales. Las ideas evolucionistas condujeron a un enfrentamiento crítico a las concepciones creacionistas religiosas como se observa en Víctor Hugo Tamayo quien también fue profesor de la Universidad de La Habana.

En algunos casos, el libre pensamiento adoptó expresiones no sólo anticlericales, si no ateas (véase: Simón, 1912) incluso, como en Francisco González del Valle (1914), que encontraron la aprobación y apoyo de Enrique José Varona o en Pedro de Armas, quien arremetió contra el espiritismo y en general contra todas las ideas religiosas (1921).

El desarrollo de investigaciones filosóficas sobre la educación encontró en el Director de la Escuela Normal de Maestros de La Habana, Arturo Montori de Céspedes, una gran elaboración articulada con posiciones epistemológicas de clara orientación materialista, pues para él, el desarrollo de la filosofía se había logrado cuando la religión perdió su eficacia ideológica (1920). A su juicio: "las religiones atendidas en su aspecto filosófico, esto es, como tentativa más o menos compleja de explicar el mecanismo del universo y la significación de la vida, han perdido en nuestros días toda virtualidad" (Montori, 1914, p. 4). Se planteó la tarea filosófica de reformar la educación cubana sobre la base de los avances de la ciencia en el naciente siglo XX, con criterios de optimismo epistemológico frente al agnosticismo y el irracionalismo que tomaba fuerza en esa época. Su postura estuvo acorde con las transformaciones sociales que reclamaban sus críticas al capitalismo, aunque sus ideas respeto a su posible transformación revolucionaria resultan algo pesimistas. Sin embargo, aun así llegó a estimular las ideas emancipatorias de la clase obrera respecto a la sociedad burguesa.

No puede dejarse de lado que las ideas de orientación socialista se habían desarrollado en Cuba desde fines del siglo XIX en Diego Vicente Tejera, así como en Carlos Baliño, quien llegaría posteriormente en 1925 a fundar junto a Julio Antonio Mella el primer 
Partido Comunista de Cuba. Y no sólo en la capital cubana habían encontrado adeptos, sino también en otras ciudades como Santa Clara aparecieron profundos y significativos cultivadores de las ideas socialistas e incluso marxistas, como Ricardo García Garófalo. Nada tiene de extraño que en la segunda y tercera décadas del siglo XX, en particular después del triunfo de la primera revolución socialista ocurrida en Rusia en octubre de 1917, aparecieran intelectuales como Montori, que sin ser militar activamente en la izquierda, llegasen a simpatizar con el ideario que se enfrentaba a la injusta y cruel sociedad capitalista.

La sociedad cubana se radicalizó en la década de los años veinte con un alto grado de profundización de la conciencia nacional y antiimperialista que se expresó en las luchas estudiantiles y obreras, apoyadas por una intelectualidad destacada y contestataria como el Grupo Minorista, frente a la dictadura de Gerardo Machado. Por supuesto que tales acontecimientos de un modo u otro repercutirían en la vida filosófica nacional y favorecerían una decantación ideológica en correspondencia con la agudización de los conflictos sociales. Montori fue uno de los que avizoró el declinar de la filosofía positivista ante el empuje de las nuevas corrientes vitalistas, irracionalistas y fideístas, que se enfrentaban al cientificismo, al ateísmo y al materialismo estimulando nuevos enfoques en los que los factores volitivos, emotivos, axiológicos, estéticos, etc., ocupaban un lugar preponderante.

La filosofía de la educación en esa etapa tuvo también en Alfredo Aguayo una significativa atención -como se puede apreciar en sus obras El método funcional en la educación (1915) y Filosofía y nuevas orientaciones en la educación (1932)-, aunque en una postura muy distante a la de Montori, y en general de la destacada tradición filosófica cubana representada por Varona, pues en su identificación con el idealismo filosófico, su defensa de la educación religiosa y sus coqueteos con el pragmatismo, a pesar de su análisis crítico de esta corriente, que intentaba encontrar adeptos en el ambiente intelectual cubano.

Una de las personalidades más relevantes en la vida filosófica cubana de la primera mitad del siglo XX fue, sin dudas, Fernando LLes. En su obra La sombra de Heráclito (1923, p. 165) se aprecia una severa crítica al espiritualismo y al idealismo filosófico, y en particular de Platón (Lles, 1924, p. 77). Al identificarse con las concepciones materialistas de Heráclito y Demócrito.

Bien es cierto que la huella de Nietzsche fue muy marcada en toda su obra, pero en especial, lo referido a su crítica a la religión por el lastre que ésta impone al progreso social y la necesidad de una transmutación de valores en la sociedad en que vive. Si algo heredó de la tradición positivista sin que llegara a identificarse con ella fue la crítica a las filosofías de corte especulativo. Su optimismo epistemológico se aprecia cuando plantea que: "no importa que esté o no esté allí el conocimiento. Tú debes conquistarlo definitivamente" (Lles, 1923, p. 165), aunque, según Miguel Rojas Gómez (1996, p. 100), en Lles "hay una exageración de la función gnoseológica de la intuición, reminiscencia de la subversión filosófica hecha por Schopenhauer y Nietzsche".

En el plano sociopolítico -en el que le dedicaría mucha atención al tema de la relación del individuo ante el estado que había preocupado con anterioridad a Spencer (véase: Lles, 1934)- el pensamiento de Lles se caracterizó por reconocer la validez de la existencia de leyes sociales en las que la huella de darwinismo social también de raigambre positivista se hizo presente; sin embargo, sus frustraciones ante la república neocolonial lo condujeron también a formular severas críticas al capitalismo, aunque se dejo confundir por las 
teorías corporativistas con disfraz socialista de Mussolini, dada su postura liberal de izquierda articulada con elementos de nacionalismo y antiimperialismo.

El vitalismo y el irracionalismo, que tomarían fuerza en esa época, encontraron en Alberto Lamar Schweyer -quien publicó numerosas obras filosóficas a uno de sus seguidores más destacados; identificado también con empirismo subjetivista e idealista de corte berkeleyano- que le hizo llegar a sostener que "el mundo exterior se reduce sólo a un conjunto de sensaciones" (1922, p. 122), se opuso abiertamente al materialismo filosófico al considerarlo primitivo, metafísico e indemostrable (Schweyer, 1922, p. 122). Sus ideas sociopolíticas caracterizadas por el social darwinismo y el racismo más reaccionario en las que la igualdad y la democracia eran considerados palabras sin sentido (Scweyer, 1927 , p. 61) sirvieron al fundamento ideológico fascistoides del grupo terrorista $\mathrm{ABC} y$ de la dictadura de Gerardo Machado, de la cual fue un fiel sirviente.

Vinculado también a esa línea de corte idealista y de postura ideológico conservadora se destacó en esa época Mariano Aramburu y Machado, quien sobre todo se dedicó al cultivo de la filosofía del derecho. Intentando asumir una postura igualmente distante del sensualismo y el racionalismo se orientó hacia el fideísmo religioso al tratar de encontrar una armonía entre la razón y Dios. Llegó incluso a procurar fundamentar científicamente las ideas religiosas, y planteó la existencia de insalvables obstáculos ante la posibilidad de la cognoscibilidad del mundo (Aramburu, 1927, p. 86).

Sus ideas filosóficas en el plano social se caracterizaron por su biologicismo y psicologismo, que trataba de evadir la raigambre económica de los procesos sociales e intentar justificar las desigualdades sociales, eternizar las diferencias de clases y el estado capitalista unido a recalcitrantes críticas al socialismo y al marxismo.

Las ideas marxistas si bien habían tenido desde fines del siglo XIX cierta recepción y difusión en el plano sociopolítico, sin embargo, en su amplitud filosófica tendrían que esperar hasta la tercera década del siglo $\mathrm{XX}$ para que comenzara su cultivo en el ambiente académico e intelectual con mayor vuelo teórico (véase: Guadarrama, 1988, pp. 16-36). Incluso, usualmente no aparecían en los programas de estudio de filosofía y posteriormente sólo comenzaron a ser objeto de estudio de quienes se dedicaban a la economía, la sociología o la teoría política.

En la Universidad de La Habana se controló mucho durante la República neocolonial el acceso de profesores de filiación comunista, aun cuando tuvieran la mejor formación académica. De tal modo, las ideas filosóficas del marxismo circularon poco en el ambiente universitario y tuvieron lógica y mayor difusión entre algunos intelectuales como Juan Marinello, Carlos Rafael Rodríguez o Alejo Carpentier o entre dirigentes políticos y sindicales como Blas Roca, Lázaro Peña, etc., quienes no se dedicaban profesionalmente a la filosofía. Pues Gaspar Jorge García Galló quien después del triunfo revolucionario se destacaría por su dedicación al estudio de la filosofía marxista, tuvo que dedicarse a la enseñanza de latín, griego o pedagogía en aquellos tiempos en que no se le permitía tener acceso a una cátedra de filosofía.

En algunos de los cursos de Historia de las Ideas Sociales impartidos a partir de la década del cuarenta en la Universidad de La Habana por Raúl Roa García, de Historia de la Filosofía por Jorge Mañach y de Sociología por Roberto Agramante la filosofía marxista encontró, en ocasiones, alguna ligera atención con distanciamiento crítico al ser reducida en la mayoría de las veces a su expresión soviética de la época del estalinismo que era la 
más difundida y común. Es oportuno recordar que muchas de las obras filosóficas de Marx y Engels en este período no eran conocidas ni siquiera por quienes se consideraban marxistas, ya que no habían sido publicadas, aún por esos años, o apenas comenzaban a publicarse. Otra de las personalidades más relevantes de la vida filosófica e intelectual cubana, en general, entre la tercera y la quinta década del pasado siglo XX, fue: Jorge Mañach. Tanto su labor docente y como brillante ensayista lo llevaron continuamente al cultivo de la filosofía, y en especial, de temas sobre la cultura.

Sus estudios en Estados Unidos le facilitaron ocasionales acercamientos al pragmatismo, pero también su estancia en España le posibilitó profundizar en las nuevas corrientes filosóficas de su tiempo, en particular, la fenomenología, la filosofía de la vida y el existencialismo, -sobre todo las ideas de José Ortega y Gasset, Nietzsche y Bergson-, a quienes le dedicaría especial atención. Acorde con las preocupaciones de su época abordó el tema del papel de la individualidad y la transmutación de valores sugerida por Nietszche. La problemática axiológica ocupó gran parte de la atención de Mañach así como la determinación de la especificidad del saber filosófico en el que la intuición, a su juicio, desempeña un papel protagónico. "Lo filosófico,-aseguraba- es casi por definición, lo no científico, lo no demostrable experimentalmente; es una personal certidumbre que se apoya, cuando más, en las razonables conjeturas que la ciencia y la intuición parecen autorizar" (Mañach, 1951, p. 23).

Contribuyó al impulso dado al estudio del pensamiento y la vida de José Martí, así como a la profundización sobre el tema de la existencia y particularidades de la filosofía en Cuba y en Hispanoamérica, que por aquellos años tomara fuerza en el ámbito continental. Se planteó la tarea de la necesidad de construir un pensamiento filosófico que dejara atrás las características reproductivas en relación con la filosofía europea. Propuso el condicionalismo (Mañach, 1951, p. 49) como una tesis que propiciara la construcción de un pensamiento original y renovador de la producción filosófica de estas tierras.

En su filosofía de la historia Mañach otorgó mayor significación a las élites minoritarias que a los sectores populares. Aquí la huella de Nietzsche y de Carlyle se aprecia claramente en esa visión aristocrática del progreso social en que la espontaneidad y la contingencia ocupan un relevante lugar. La obra intelectual de Mañach constituye una de las expresiones de la revitalización de la producción filosófica cubana que se observa desde mediados de los años cuarenta, cuando se funda la Sociedad Cubana de Filosofía y aparece la Revista Cubana de Filosofía que durante la década del cincuenta impulsaran, entre otros, Roberto Agramonte, Rafael García Barcena y Humberto Piñera Llera.

Con el inicio de la década del cuarenta la publicación de la colección Biblioteca de Autores cubanos, por parte de la Universidad de La Habana, dirigida por Roberto Agramonte, quien además publicó varios trabajos sobre la historia de la filosofía en Cuba ${ }^{13}$, constituyó un acontecimiento cultural de extraordinaria significación que se revierte en la docencia y en el trabajo investigativo con múltiples aportes. Cada obra de esa colección fue precedida de un estudio preliminar que demostraba la riqueza contenida en el pensamiento cubano, fundamentalmente del siglo XIX.

13 Además de su libro sobre José Agustín Caballero, Roberto Agramante publicó entre otros: Prefacio a la filosofias cubana. En Revista Cubana de Filosofia, 3, 4-11. La Habana; Situación de la filosofía cubana. En Revista Cubana de Filosofia, 4, 4-8. La Habana. "Los grandes momentos de la filosofía en Cuba". En Revista Universidad de La Habana, 91-93, 7-20; Varona, el filósofo del escepticismo creador. (1949). La Habana: Editorial Jesús Montalvo. 
Roberto Agramonte fue profesor de Sociología General y Filosofía Moral en la Universidad de La Habana desde los años treinta, aunque se destacó internacionalmente mucho más por sus estudios sociológicos, sin embargo, su contribución a los estudios de la vida filosófica nacional resultaron también muy valiosos.

Su pensamiento filosófico se articuló a la tradición idealista e irracionalista que había ido tomando fuerza desde el inicio del siglo XX. A su juicio: "el mundo social está constituido por seres que deciden sus actos en virtud de las operaciones de su conciencia o espíritu" (Agramonte, 1959, p. 2), como si las condiciones económicas y políticas no tuvieran mucho que ver con el mismo. Lógicamente tal concepción lo condujo a un enfrentamiento crítico de la concepción materialista de la historia formulada por el marxismo, al cual consideraba como monista determinista y simplificador del papel de la lucha de clases, la cual subestimaba. Tal postura articulaba con su oposición al ideario socialista que le hizo al igual que a Mañach rechazar la radicalización hacia el socialismo que se produjo en el proceso revolucionario cubano a inicios del sesenta.

Algo similar ocurriría con otra relevante figura de la vida filosófica cubana Humberto Piñera Llera, quien llegó también a presidir la Sociedad Cubana de Filosofía, la cual a juicio de Carlos Rafael Rodríguez produjo una "desdichada ruptura con la tradición filosófica cubana” (Rodríguez, 1983, p. 124). Su clara identificación con la filosofía de la vida y el existencialismo lo condujeron a hiperbolizar la existencia individual humana (Piñera, 1952, p. 93) como el pilar sobre el cual descansa todo el andamiaje de la realidad, al considerar que "la existencia es algo que cada quien intuye directamente. Intuimos que hay algo que no somos nosotros mismos si no otras cosas u objetos que se nos oponen y nos hacen resistencia" (Piñera, 1954, p. 43).
Al otorgarle precedencia a la existencia en relación con la esencia, lo hacía desde las posiciones del idealismo y el irracionalismo, ya que según Piñera (1952, p. 85) "hay que admitir la realidad de lo irracional... y hay algo más: que esta irracionalidad, lejos de ser condición peyorizante, es signo de dignidad epistemológica igual a la que exhibe la definición y el concepto".

La labor filosófica e intelectual, en general, de Jorge Mañach, Roberto Agramonte y de Humberto Piñera Llera se mantuvo muy activa también, como lo evidencian sus últimas publicaciones, algunas de ellas publicadas post mortem, después que decidieron emigrar de Cuba a causa de sus discrepancias con la orientación socialista de la Revolución.

La filosofía en Cuba encontró en Rafael García Barcena, una regia personalidad que incursionaría en temas de profundo contenido ontológico como la estructura del mundo biofísico en cuyo análisis combina elementos evolucionistas sobre la materia con una profunda convicción creacionista y religiosa del mundo. Su libro Estructura de la estructura obtuvo el Premio Nacional de Filosofía en 1950 y fue publicado en Argentina con un prólogo del destacado pensador de ese país Francisco Romero. Sus libros Individualización de la ética (1939) y Esquema de un correlato antropológico en la jerarquía de los valores (1943) confirman la existencia en esta época de gran interés por los temas axiológicos y éticos en la filosofía cubana.

Resulta altamente interesante y ejemplar que este prestigioso profesor de Filosofía Moral de la Universidad de La Habana desde su profunda ética religiosa, que concebía que "el hombre se siente dependiente de una realidad superior a su propio ser individual, la que por ello debe regir toda su vida" (García, 1943, p. 2) y por tanto creyera que la verdadera felicidad y salvación del hombre estaba en el reino celestial, se opusiera de forma activa y 
revolucionaria al golpe de estado de Fulgencio Batista y haya organizado con algunos de sus estudiantes -entre los cuales se destacara Faustino Pérez y Armando Hart Dávalos-, el Movimiento Nacional Revolucionario que concibió, mucho antes que Fidel Castro, la idea de asaltar un cuartel militar y levantar al pueblo contra aquella dictadura.

El fracaso de ese intento lo condujo a la cárcel, desde donde escribió otra de sus obras filosóficas más relevantes, en la que la que su convicta fe cristiana pareciera no contradecir su postura humanista revolucionaria (véase, García, 1956), que lo hizo mantenerse firmemente activo tras el triunfo de enero de 1959, hasta su muerte, como embajador en Brasil de su pueblo y su Revolución.

En esos años Medardo Vitier alcanza un merecido reconocimiento internacional, especialmente latinoamericano, no sólo por sus más conocidas obras Las ideas en Cuba (1938) y La filosofía en Cuba (1948), sino por otros estudios dedicados a Varona, Martí y otros temas de la vida filosófica cubana y del pensamiento de Kant (véase: Vitier, 1970/2004). Debe destacarse que esta generación filosófica cubana de mediados del pasado siglo XX tuvo una relevante actividad internacional, en particular en el ámbito americano, como lo demuestra su frecuente participación en congresos de filosofía y en la publicación de sus trabajos en España, Estados Unidos y varios países latinoamericanos. Al mismo tiempo, relevantes filósofos extranjeros visitaron a Cuba y ofrecieron conferencias, como los mexicanos José Vasconcelos, y Leopoldo Zea y a raíz del exilio provocado por la caída de la República española llegaron José Ferrater Mora, José Gaos, María Zambrano, entre otros, así como el peruano Francisco Miró Quesada.

Es necesario destacar que algunos relevantes intelectuales cubanos cuya actividad básica no era propiamente la filosofía; sin embargo, en algún momento incursionaron también en ella, incluso con trabajos específicos con este perfil, como Fernando Ortiz en La filosofía penal de los espiritistas (1915) o Ramiro Guerra con Filosofía de la producción cubana (1944), Alejo Carpentier, entre otros, incursionaron a su manera en este terreno.

Varios fueron los nombres que se incorporaron a este breve bosquejo que contribuyó a evidenciar la diversidad de posiciones filosóficas que se manifiestaron en Cuba durante la primera mitad del siglo XX, pero de lo que se trata es solamente de ofrecer un panorama de algunos de los principales representantes, tendencias y problemas que se observaron en esta etapa de la historia nacional. Como puede apreciarse, la actividad filosófica en Cuba durante la etapa de la república neocolonial fue objeto de múltiples transformaciones en relación con la que había tenido en el siglo XIX, pues aunque el positivismo continuó manteniendo alguna repercusión al menos en las dos primeras décadas del siglo XX, también fue languideciendo ante los ataques del irracionalismo, el vitalismo y la reinstalación del fideísmo.

La raigambre materialista y la preocupación por la cuestión de encontrar el mejor método del conocimiento que se había apreciado en el pensamiento cubano decimonónico se debilitó, dado el auge que tomarían cultivos especulativos de la filosofía, más orientados hacia el idealismo en sus diversas modalidades. La concepción materialista de la historia, la naturaleza y el pensamiento propugnada por el marxismo impulsó su despliegue más allá del pensamiento político donde se había iniciado, pero encontró serios obstáculos para cultivarse en las universidades.

El pragmatismo tuvo pocos cultivadores en tanto la fenomenológica, el existencialismo y neotomismo encontrarían algunos seguidores destacados no sólo en la educación superior sino también en el nivel de bachillerato, don- 
de muchos de los textos eran de los mismos profesores universitarios. Algunos de esos textos se reeditaron en otros países latinoamericanos. La filosofía analítica de orientación neopositivista apenas contó con muy pocos cultivadores como era común en esa época en toda Latinoamérica.

Debe destacarse la diversidad de disciplinas y temas de carácter filosófico que eran objeto de estudio, en especial la valoración de las grandes personalidades del siglo XIX cubano que enaltecieron la filosofía, así como en incremento considerable de publicaciones y de eventos de carácter filosófico, fundamentalmente entre los años cuarenta y cincuenta. A la vez resulta evidente que aquel compromiso orgánico con las necesidades sociopolíticas y participación activa en las luchas de su época, que había caracterizado a los pensadores cubanos del siglo XIX no fue lo más común a las nuevas generaciones de profesionales de la filosofía en esta etapa, con las escasas excepciones que hemos anteriormente indicado. Tal indiferencia ante las luchas del pueblo cubano frente a las dictaduras, a los gobiernos corruptos y a la injerencia norteamericana en la Isla motivaron con razón la necesaria crítica de otros intelectuales más conscientes y decididos a colaborar por dignificar la situación de la mayoría de la población y en general salvaguardar la soberanía y la identidad cultural cubana.

El triunfo de la Revolución Cubana en enero de 1959, no fue simplemente un hecho de trascendencia política. Era también un acontecimiento cultural de extraordinaria magnitud para la Isla y la región como la historia se ha encargado de demostrar. Desde un inicio quedó evidenciada la profunda raigambre martiana de su proyecto al constituirse en síntesis de las aspiraciones y proyectos de múltiples generaciones de pensadores y revolucionarios cubanos. Las fuentes teóricas y las líneas ideológicas de las que se nutrió la Revolución naciente eran heterogéneas, desde el democratismo revolucionario de José Martí, el pensamiento liberal nacional $\mathrm{y}$ antiimperialista, hasta el marxismo.

Ya en los primeros años la confrontación de proyecciones se plasmó no sólo en el proyecto político cubano, sino en todo el ambiente educativo y cultural. El proceso de reforma universitaria llevado a cabo a inicios de los años sesenta, tras la proclamación del carácter socialista de la Revolución, incidió significativamente en toda la actividad filosófica del país. Ya desde el primer año de la Revolución se produjo el éxodo de filósofos comprometidos con el régimen anterior. Entre quienes permanecieron en el país se manifestaron enquistamientos de algunos por sus desavenencias con el rumbo socialista tomado por la Revolución. En tanto que otros sin abandonar consolidadas posiciones filosóficas o asumiendo una posición respetuosamente transigente ante el marxismo no encontraron serios conflictos con el nuevo gobierno y se mantuvieron hasta sus últimos días incorporados a la vida filosófica nacional, entre ellos estuvieron Justo Nicola, especialista en lógica y Antonio Sánchez de Bustamante y Montoro en filosofía del derecho. Algunos, incluso, por sus simpatías con el proceso revolucionario, articularon mejor con la nueva época de predominio del marxismo en el proceso ideológico e intelectual cubano.

En cuanto al estudio de las ideas en Cuba en general, hay que destacar que se produjo a partir del triunfo revolucionario una explosión de publicaciones e investigaciones que mostraban una riqueza extraordinaria de la producción intelectual cubana, parte de la cual había sido tergiversada y refrenada por sus proyecciones ideológicas. Una atmósfera amplia de circulación de ideas filosóficas se respiró durante la década del sesenta, que permitió incluso la divulgación de las obras de prestigiosos investigadores más allá de sus posiciones ideológicas y de diversos países, como pudo apreciarse en algunos de 
los textos de filosofía que se utilizaban especialmente en la Universidad de La Habana ${ }^{14}$, aunque en algunos casos predominaban más la reproducción de trabajos de los clásicos del marxismo-leninismo y de autores extranjeros que de autores cubanos (véase: colectivo de autores, 1966).

En el plano de la vida filosófica ese período de los sesenta se caracterizó por constituir un perenne hervidero de ideas que se evidenció desde la temprana visita de Sartre a la Isla y sus propuestas ideológicas y filosóficas, hasta las paradigmáticas posiciones del Che Guevara respecto al escolasticismo del marxismo soviético, pasando por la marcada huella de Louis Althusser ${ }^{15}$, Antonio Gramsci y en general del llamado marxismo occidental ${ }^{16}$ sobre el país (véase: Guadarrama, 1988, pp. $262,271)$.

Ya desde los años sesenta un marxismo manualesco fundamentalmente de procedencia soviética dejaba sentir su influencia en determinadas esferas de la docencia y la

14 Para profundizar pueden revisarse los textos surgidos del colectivo de autores (1969), Lecturas de filosofia. Tomo I y II. La Habana: Estudios. Colectivo de autores (1969). Selección de lecturas marxistas. Santa Clara: Universidad Central "Marta Abreu" de Las Villas.

15 A mediados de los sesenta se publicaron en Cuba y eran muy consultadas en las universidades algunas de las obras de Louis Althuser y otros filósofos franceses como Jean Paul Sartre, Pierre Machery, Balibar Etienne; así como del gran marxista italiano Antonio Gramsci. Vease: Althusser, (1966). Por Marx. La Habana: Revolucionaria; Gramsci, A. (1966). El materialismo histórico y la filosofía de Benedetto Croce. La Habana: Revolucionaria.

16 También se publicaron obras de otros marxistas usualmente considerados como revisionistas en la Unión Soviética. Tal es el caso del húngaro Geogy Lukacs, los italianos Antonio Labriola y Lucio Colleti, el alemán Herbert Marcuse, los polacos Adam Schaft e Isaac Deutscher y el hispano-mexicano Adolfo Sánchez Vázquez. investigación filosófica del país. Pero su predominio se haría sentir mucho más, durante la década del setenta hasta principios de la del ochenta y produjo cierto enquistamiento en la producción filosófica nacional, así como en otras esferas de las ciencias sociales. El efecto de las interpretaciones simplificadoras del desarrollo de las ideas filosóficas se hizo sentir de algún modo también en los estudios sobre sus manifestaciones y la historia de las ideas en general en Cuba.

Un factor que tendría alguna incidencia en la orientación que tendría el desarrollo de la filosofía marxista en Cuba estuvo dado porque muchos de las nuevas generaciones de los profesionales de la filosofía comenzaron a formarse en la Unión Soviética y otros países de Europa Oriental que solidariamente ofrecían tales posibilidades a un país bloqueado y asediado por los Estados Unidos de América. También la mayor parte de las participaciones en congresos internacionales y otros intercambios se desarrollaban hasta mediados de los ochenta con especialistas provenientes de esos países.

En ese aspecto, desde inicios de los ochenta en correspondencia con las nuevas condiciones de intercambio cultural con la mayoría de los países latinoamericanos que fueron restableciendo sus relaciones diplomáticas con Cuba, se incrementó paulatinamente la participación de profesores cubanos de filosofía en eventos en estos países y se incrementaron las visitas a Cuba de profesionales de la filosofía provenientes tanto de Latinoamérica como de Norteamérica y de Europa Occidental, en especial de España. En esas nuevas condiciones se favoreció el conocimiento de nuevos autores, y corrientes del pensamiento filosófico mundial -incluso diversas tendencias dentro del marxismo-y en particular, del latinoamericano, como el postmodernismo o la filosofía de la liberación, que comenzaron a ser estudiados con nuevas perspectivas mucho más documen- 
tadas que en los años anteriores, en las que el acceso a las fuentes directas de los autores estudiados era muy limitado o mediado por las interpretaciones de los autores de los manuales correspondientes, factor éste que limitaba la objetividad en la valoración de los temas de estudio.

Desde la segunda mitad de los sesenta y fundamentalmente durante la década de los setenta, la mayor parte de los textos universitarios de filosofía en sus distintas especialidades -con escasas excepciones (véase: Nicola, 1968, Tomos I y II; Colectivo de autores, 1979)-, eran de autores soviéticos o de otros países socialistas de Europa Oriental, en menor grado. La mayor parte de los profesores de filosofía se limitaba a reproducir en sus clases las ideas y hasta los programas docentes importados de la URSS fenómeno éste que limitó en alguna medida la creatividad de los autores cubanos. En otras ocasiones dedicaban gran parte de sus páginas a reproducir textualmente documentos programáticos de los congresos del Partido Comunista de Cuba (véase: Suárez, S. f.).

Esta situación comenzó a modificarse a mediados de los ochenta ${ }^{17}$ cuando se constituyen varios colectivos de autores cubanos para elaboración de textos de filosofía-labor ésta que se intensifica y renueva a inicios de la

17 Para profundizar en este tema, puede consultarse: Colectivo de autores. (1985). Felipe Sánchez Linares (dir.). Lecciones de Filosofia Marxista-leninista. Tomos I y II. La Habana: Universidad de La Habana; Colectivo de autores. (1986). Manual de filosofía marxistaleninista. Materialismo dialéctico. La Habana: Editora Política; Colectivo de autores (1986). Manual de filosofia marxista-leninista. Materialismo histórico. La Habana: Editora Política; Colectivo de autores. (1987). Juan Francisco Fuentes (comp. e introducción). Filosofía marxista-leninista Selección de lecturas. I-II. La Habana: Universidad de La Habana. década de los noventa ${ }^{18}$ - junto a esta labor se intensifica la publicación de otros libros de autores nacionales y extranjeros sobre diversos temas de las diferentes disciplinas filosóficas.

Entre los principales temas que se incrementarían considerablemente los estudios por parte de autores cubanos se encuentran el relacionado con las categorías ${ }^{19}$ y la especificad del saber filosófico (véase: Rodríguez, 1984), los problemas filosóficos de la ciencia y la tecnología (véase: Núñez, 1987; Sánchez, 1988): cuestiones lógicas (Rodríguez, 1983) y epistemológicas de los métodos del conocimiento científico (Colectivo de autores, 1981; Mateo, 1986) y filosófico, temas axiológicos (véase: Rodríguez, 1985; Fabelo, 1989; 1996), de filosofía política (Acanda, \& Martínez, 1997), en especial referida a la cuestión del Estado (véase: Fernández, 1988), las clases sociales, la revolución social y el socialismo (véase: Fung, 1982; Martínez, 1988), la filosofía de la cultura (véase: Guadarrama \& Pereliguin, 1988/1989/1998), la cuestión de la identidad cultural (véase: Ubieta, 1993; González, Ichikawa \& Rojas, 1997), cuestiones de estética (véase: Fernández, L. \& Fernández, A., 1974/1987) y de ética (véase: Ulloa \& Chacón, 1988; Mari, 1988; Colectivo de autores, 1990, Tomos I-III), y de metódica de la enseñanza de la filosofía (véase: Aguilar, 1979; Martínez, 1987), etc. También se incrementaron los estudios sobre la historia de la filosofía tanto de la europea antigua,

18 Para profundizar verse: Colectivo de autores. (1991). Pablo Guadarrama (dir). Lecciones de Filosofía Marxista-leninista. Tomo I. La Habana: Editorial Félix Varela; (1992/2000). La Habana: Editorial Pueblo y Educación.

19 Acerca de este punto, recomiendo revisar: García. (1984). Categorías del materialismo dialéctico. La Habana: Gente Nueva; Pupo. (1986). La práctica y la filosofía marxista. La Habana: Ciencias Sociales; (1990) La actividad como categoría filosófica. La Habana: Ciencias Sociales. 
moderna y contemporánea (véase: Rensoli, 1987; 1986; Santos, 1988; Colectivo de autores, 2000), especialmente el postmodernismo (véase: Guadarrama, 1994; García, 1994; Ravelo, 1996; Fung (dir.), 1999; Colectivo de autores, 2000), como de la latinoamericana ${ }^{20}$ y cubana ${ }^{21}$, en particular del desarrollo del marxismo ${ }^{22}$, sobre todo algunos dedicados a estudiar las transformaciones que se han operado en el pensamiento marxista en América Latina especialmente en los últimos años tras el derrumbe del socialismo real (Colectivo de autores, 1999).

Desde mediados de la década del los noventa y particularmente luego de transcurridos algunos años de recuperación de la economía cubana, cuyos efectos se hicieron sentir en todos los órdenes de la vida social, cultural e ideológica, el país, y por tanto, la producción filosófica no podía estar al margen de las secuelas negativas de esos años de crisis, la vida filosófica cubana se reanimó significativamente, como se evidencia en las publicaciones, congresos, debates, entre otros, de esta última etapa.

Finalmente, el despliegue y radicalización de una intelectualidad cubana de izquierda ha dado lugar a una recepción muy propia del marxismo durante más de cuatro décadas con perspectivas de continuidad y enriquecimiento muy lejos de los masivos suicidios teóricos e ideológicos de los marxistas vergonzantes, que se produjeron en muchos países tras la caída del muro de Berlín.

20 Recomendamos: Monal, (1985); Rivero, (1987); Rensoli, (1988); Colectivo de autores, (1991/1993); Guadarrama (dir.); Plá León, (1994); Colectivo de autores, (1998); Guadarrama (coord.).

21 Para profundizar puede consultarse: Miranda, (1984; 1989; 1997; 1994).

22 Recomendamos profundizar en: García (1982); Colectivo de autores (1997); Guadarrama (1998; 1990; 1994).
En los primeros años del siglo XXI, aunque aún se continúan utilizando en ocasiones algunos textos para la enseñanza general de la filosofía elaborados a fines del siglo XX, -algo muy diferente ha sido en las carreras específicas de filosofía, en las cuales ha prevalecido mayor versatilidad de enfoques y fuentes bibliográficas- comenzaron a elaborarse nuevos textos con criterios más amplios y versátiles sobre algunos de los problemas tradicionales y otros más actuales de la filosofía (Colectivo de autores, 2000-2002). Nuevas investigaciones han aparecido sobre la filosofía contemporánea (véase: Sardoya, 2000; Ravelo, 2003), problemas filosóficos de la cultura (Jardines, 2004), la ideología (Días, 2001), axiología (Fabelo, 1996), los derechos humanos (Limia, 2001), etc. A la vez se mantiene el interés por el estudio del pensamiento filosófico latinoamericano (Colectivo de autores, 2002) especialmente su tradición humanista (Guadarrama, 2001; Monal \& Miranda, 2002).

A la hora de valorar la producción filosófica cubana de los últimos tiempos no se debe tomar en consideración solamente los trabajos publicados en forma de libros, artículos o ponencias presentadas en congresos, sino también las numerosas tesis doctorales y de maestría, que la mayoría de ellas no están publicadas, y que demuestran el interés por diversos temas entre los cuales se encuentran las ideas filosóficas de José Agustín Caballero, José de la Luz y Caballero, Enrique José Varona, José Martí, Carlos Baliño, Julio Antonio Mella, Raúl Roa, Ernesto Guevara, José Carlos Mariategui, José Ingenieros, Leopoldo Zea, Enrique Dussel, Adolfo Sánchez Vázquez, José Ortega y Gasset, etc. Así como diversas etapas de la vida filosófica cubana y latinoamericana o problemas epistemológicos, axiológicos, éticos, estéticos, de filosofía política, entre otras.

Resulta destacable el hecho de que algunos científicos cubanos, especialmente desde 
la matemática (Casanova, 1965), la física (Castro, 1998), la medicina (Colectivo de autores, 1986; 1987) y las ciencias sociales (Aguirre, 1996; Colectivo de autores, 1982) hayan incursionado también en los últimos tiempos en temas filosóficos. Una significativa irrupción o reactivación de revistas en el área de las ciencias sociales como Temas, Contracorriente, La Gaceta de Cuba, Revista Cubana de Ciencias Sociales, Islas, etc., han propiciado el notable impulso retomado por la vida filosófica cubana de los últimos años.

Un esbozo de los rasgos principales del estado actual de la filosofía en Cuba en los inicios del siglo XXI puede inducir a apuntar las siguientes características, que reclaman lógicamente una mayor fundamentación en investigaciones sobre el tema, de las cuales algunas actualmente se desarrollan:

- Prevalece una declaración oficial de la orientación marxista-leninista de la enseñanza de la filosofía en los distintos niveles de la educación. Los textos que usualmente se utilizan, así lo atestiguan. Sin embargo, en comparación con programas anteriores hay una mayor amplitud de contenidos a tratar, interpretándose desde el marxismo, problemas de actualidad, condicionados por la desaparición del socialismo europeo, la globalización, la ofensiva neoliberal, la problemática de la identidad cultural, etc. En los nuevos programas de estudio de filosofía para la enseñanza general existe relativa unidad por medio de los llamados "temas invariantes" es decir, de obligatorio tratamiento en los programas establecidos, teniendo la posibilidad cada universidad y cada departamento o profesor de adecuar los mismos a sus especificidades.

- Se han ido superando algunas posturas dogmáticas y simplificadoras de la dialéctica materialista dentro de la propia teoría marxista que se observaba en épocas anteriores, en correspondencia con distintas interpretaciones de lo que se entiende por marxismo y la admisión o no de crisis del mismo como filosofía, al igual que ha sucedido y sucederá con otras corrientes filosóficas.

- El rigor académico ha posibilitado una mayor producción intelectual que, por paradójico que pudo resultar, se creció en momentos difíciles de carencias materiales y dificultades de publicación, lo que dio lugar a que estas ideas circularan en mayor medida a través de eventos, talleres, tertulias, correo electrónico, soportes magnéticos, redes informáticas, etc.

- La limitación en cuanto al acceso bibliográfico a obras filosóficas más recientes ha impedido que haya habido una mayor comunicación actualizada entre los especialistas de diversos temas filosóficos y sobre todo de nivel de profundización y actualización sobre los nuevos desarrollos teóricos de la filosofía contemporánea, agudizándose más esta situación en determinados centros de educación superior. Este obstáculo ha sido frecuentemente superado, gracias al acceso a Internet en las universidades, aunque también con las limitaciones de acceso a algunas fuentes que esta vía presupone, pero en general ha mejorado mucho este problema de la información actualizada, aunque no en forma generalizada, por algunos colectivos filosóficos. En algunos casos aquella situación de relativo aislamiento informático generó una proyección reproductiva y mecánica de algunas teorías, pero gracias a un considerable incremento del intercambio académico internacional de los profesionales cubanos de la filosofía por frecuentes invitaciones a conferencias, eventos, cursos de postgrado e intercambio bibliográfico se tiene acceso a las nuevas corrientes y problemas de la 
filosofía contemporánea, en un esfuerzo de actualización.

- Ha prevalecido una marcada tendencia hacia el predominio de la filosofía política, motivada por las urgencias y condicionamientos generados por la difícil situación socioeconómica del país de la década de los noventa. En la docencia universitaria se ha conservado e incluso incrementado la enseñanza de la ética, la historia de la filosofía, la estética, en tanto que la lógica, la epistemología, la filosofía de la ciencia y la axiología han encontrado una recepción relativamente inferior, aunque cuentan también con cultivadores significativos.

- La labor investigativa por lo regular se revierte en la docencia universitaria de manera directa, aunque no quede plasmada siempre en textos y otras publicaciones de amplio acceso. La oralidad, como en la antigüedad, ha desempeñado nuevamente una función esencial en el desarrollo del pensamiento filosófico contemporáneo. No deja de existir, como en todas partes, un limitado sector de profesores meramente reproductivos de teorías filosóficas, que asumen esta profesión como un modus vivendi y resultan poco aportadores y creativos.

- El incremento de las visitas de filósofos extranjeros de distintas corrientes del pensamiento universal, especialmente desde los noventa, el intercambio tanto en el país como la participación de profesionales cubanos en congresos relacionados con la filosofía tanto en Cuba como en el exterior han posibilitado un recíproco estudio de las distintas corrientes filosóficas que demandan ser justipreciadas. A la vez se estima una mejor comprensión de las particularidades de la vida filosófica cubana en el exterior, a partir de tales intercambios.
- Pensar que la vida filosófica en Cuba se reduce a las universidades, centros de educación superior o instituciones académicas, que en todos los casos son públicas, exclusivamente es un error, pues también en seminarios religiosos y otras instituciones culturales y publicaciones no estrictamente filosóficas, la filosofía se cultiva también con relativa intensidad.

- La actividad filosófica en Cuba no ha sido tampoco, como en todas las épocas y circunstancias, actividad exclusiva de filósofos profesionales. Tanto la obligatoriedad de la enseñanza de la filosofía en todas las carreras universitarias, como los cursos de postgrado de filosofía para todo tipo de profesionales, así como la lógica preocupación intelectual que motiva a muchos de ellos a abordar problemas cosmológicos, epistemológicos, éticos, etc., ha dado lugar a que la filosofía en Cuba haya alcanzado un determinado reconocimiento académico y social. Sin embargo, la filosofía no ha dejado de ser afectada en su status en los últimos tiempos, como en general ha sucedido con las ciencias sociales y las humanidades dado el triunfo de criterios pragmáticos ante la crisis de valores provocada por el desastre del socialismo.

- No parece ser apropiada la denominación de escuelas de pensamiento para clasificar el ambiente filosófico cubano contemporáneo. Fue propio del mismo desde el siglo XIX no dejarse seducir por grupos formales conformados, ni siquiera por pensadores o corrientes de pensamiento exclusivos. Tal vez por esa razón el propio marxismo ha tenido también diversas lecturas en la Isla.

Como ha podido apreciarse en esta apretada síntesis, Cuba tiene razones suficientes para sentir orgullo del desarrollo que ha tenido la 
filosofía en el país, y particularmente, por el papel que han desempeñado sus principales representantes, fundamentalmente del siglo XIX, en la conformación de su identidad y cultura. Las distintas etapas por la que ha atravesado la vida filosófica cubana han estado articuladas al desarrollo a nivel mundial de las distintas corrientes que han ido tomando fuerza protagónica o relativo abandono, en correspondencia con las exigencias epistemológicas, axiológicas, ideológicas o científicas de cada época a escala universal, pero también a los diferentes momentos de la historia nacional que han demandado de los cultivadores de la filosofía, no solo profundas reflexiones teóricas y sistemas categoriales de explicación de la realidad, sino también, actitudes prácticas de compromiso orgánico para su transformación y humanización.

La filosofía por sí misma no es capaz de transformar el mundo, pero tampoco es posible hacerlo prescindiendo de ella. La ciencia, la técnica, el arte, la política, el derecho, etc. constituyen diversas posibilidades de contribución al mejoramiento humano cuando se orientan por principios humanistas y desalienadores que jamás podrán desempeñar a plenitud sus respectivas tareas, si no están avalados por el saber filosófico.

Una de las especificidades de dicho saber es potenciar la capacidad crítica y creativa del pensamiento humano en permanente constatación con los resultados de afectación o perfeccionamiento del mundo natural y social de acuerdo a como plasma la historia. La filosofía no abandonará jamás su función, entre las múltiples que desempeña ${ }^{23}$, de vigilia

23 Véase: Guadarrama, P. (1998). ¿Para qué filosofar? (Funciones de la filosofía). Revista de filosofia, 30, 109-139. Centro de Estudios Filosóficos “Adolfo García Díaz”. Universidad del Zulia. Maracaibo. Reproducido en Filosofía y Sociedad, Tomo I y II. (Director Pablo Guadarrama). La Habana: Editorial Félix Varela.. 2000, 2001, 2002, p. 44-69. epistemológica y axiológica que posibilitan al ser humano construir realidades nuevas a partir de la potencialidad creativa del pensamiento cuando se articula adecuadamente con la praxis social.

Si bien puede que algunos profesionales cubanos de la filosofía en determinados momentos de la historia nacional pensaron que la razón de ser de la filosofía se agotaba en ella misma y, que simplemente replantearse los ancestrales problemas filosóficos en las nuevas circunstancias, sin proyectarse hacia la transformación de las mismas, afortunadamente estos fueron minoría. La mayoría de las mujeres y hombres que en Cuba han consagrado su actividad intelectual a la filosofía lo han hecho con plena conciencia de su utilidad social y su retroalimentación en la realidad que ha demandado no sólo interpretaciones sino transformaciones radicales. También aquí la filosofía se ha nutrido, no sólo de la tradición filosófica y cultural nacional, continental y mundial sino de los conflictos permanentes del ser humano ante la naturaleza y la sociedad que obligan a toda persona culta a hacer progresar la filosofía para que ella también contribuya al progreso de este mundo y si sirve también para hacer progresar a otros, pues bienvenida sea.

\section{Referencias}

Acanda, J. \& Martínez, F. (1997). Filosofar con el martillo. La Habana: Centro de Investigación y Desarrollo de la Cultura Cubana Juan Marinello.

Aguilar, C. (1979). Metódica para la enseñanza de la filosofía marxista-leninista. Camaguey: Universidad de Camaguey.

Agramonte, R. (1959). Introducción a la sociología. La Habana: Publicaciones Culturales. 
Aguirre, J. (1986). Filosofía y economía política marxistas. La Habana: Ciencias Sociales.

Alfonso, G., Ichikawa Morin, E. \& Rojas, M. (1997). La polémica sobre la identidad. La Habana: Ciencias Sociales.

Aramburo, M. (1927). Filosofía del derecho, Tomo I. La Habana: (S. e.).

Armas, P. (1921). Sondeando el espiritismo. La Habana: Imprenta Siglo XX.

Arce, A. (1996 mayo-junio). La enseñanza filosófica del siglo XVIII en la Real y Pontifica Universidad de San Gerónimo. En Revista Universidad de La Habana, 179.

Arce, A. (1996 julio-agosto). El seminario de San Basilio el Magno en Santiago de Cuba. En Revista Universidad de La Habana, 180.

Bachiller \& Morales, A. (1857). Elementos de filosofía del derecho o Curso de derecho natural. La Habana (S. e.).

Bachiller \& Morales, A. (1936). Apuntes para la historia de las letras y la instrucción pública en la isla de Cuba. La Habana: Editorial Cultural.

Busch, R. (2001). José Agustín Caballero. Iniciador de la reforma filosófica en Cuba. La Habana: Félix Varela.

Borge, F. (1990). Las primeras manifestaciones del pensamiento filosófico en Cuba: la escolástica como teorización del criollismo. En Revista de la Universidad Central Marta Abreu de Las Villas, 96. Santa Clara.

Caballero, J. (1944). Filosofia Electiva. La Habana: Universidad de la Habana.

Caballero, J. (1956). Escritos varios. La Habana: Universidad de La Habana.
Casanova, G. (1965). La Matemática y el materialismo dialéctico. La Habana: Editorial Nacional de Cuba.

Castro, F. (1988). Espacio y tiempo en la filosofía y la física. La Habana: Ciencias Sociales.

Colectivo de autores. (1966). Lecturas de filosofía. Universidad de La Habana. Departamento de Filosofía. La Habana.

Colectivo de autores. (1968). Lecturas de filosofía, Tomos I y II. La Habana: Estudios.

Colectivo de autores. (1969). Selección de lecturas marxistas. Santa Clara: Universidad Central Marta Abreu de Las Villas.

Colectivo de autores. (1976). Sobre la teoría marxista-leninista de la sociedad. La Habana: Orbe.

Colectivo de autores. (1981). La dialéctica y los métodos cientificos generales de investigación, Tomos I y II. Mariano Rodríguez Solveira (dir.). La Habana: Instituto de Filosofía. Editorial Ciencias Sociales.

Colectivo de autores. (1982). Anuario filosófico, Tomos I-III. Santiago de Cuba: Universidad de Oriente.

Colectivo de autores. (1985). Lecciones de Filosofia Marxista-leninista, Tomos I y II. Felipe Sánchez Linares (dir.). La Habana: Universidad de La Habana.

Colectivo de autores. (1986). Manual de filosofia marxista-leninista. Materialismo dialéctico. La Habana: Editora Política.

Colectivo de autores. (1986). Manual de filosofía marxista-leninista. Materialismo histórico. La Habana: Editora Política.

Colectivo de autores. (1986). Problemas filosóficos en la medicina, Tomos I-III. 
La Habana: Instituto Superior de Ciencias Medicas de La Habana.

Colectivo de autores. (1987). Filosofía marxista-leninista Selección de lecturas. I-II. Juan Francisco Fuentes (compilación e introducción). La Habana: Universidad de La Habana.

Colectivo de autores. (1987). Filosofia y medicina. La Habana: Editorial Ciencias Sociales.

Colectivo de autores. (1990). Estudios éticos. López Bombino, L. R (Compilador). Tomos I-III. La Habana: Universidad de La Habana.

Colectivo de autores. (1991, mayo-agosto). Humanismo y Filosofía de la Liberación en América Latina. Pablo Guadarrama (dir.) En: Revista Islas Universidad Central Marta Abreu de las Villas, 99. Santa Clara. (Reimpresión,1993). Bogotá: El Búho.

Colectivo de autores. (1991). Lecciones de Filosofía Marxista-leninista. Pablo Guadarrama (dir.). Tomo I. (2a. reimpresión). La Habana: Félix Varela. (3a. reimpresión, 2000). La Habana: Pueblo y Educación.

Colectivo de autores. (1997). Marx y la contemporaneidad, Tomos I-III. La Habana: Ciencias Sociales.

Colectivo de autores. (1998). La filosofía en América Latina. Pablo Guadarrama (Coord.). La Habana: Félix Varela.

Colectivo de autores. (1999). Despojados de todo fetiche. La autenticidad del pensamiento marxista en América Latina. Pablo Guadarrama (dir.). Bogotá: Universidad INCCA de Colombia. Universidad Central de las Villas.
Colectivo de autores. (2000). Estudios de filosofía. Una saga de la cultura cubana. Emilio Ichikawua Morin (Compilador). La Habana: Ciencias Sociales.

Colectivo de autores. (2000). Inicios de partida. Coloquio sobre la obra de Michel Foucault. La Habana: Centro de Investigación y Desarrollo de la Cultura Cubana Juan Marinello.

Colectivo de autores. (2001-2002). Filosofía y Sociedad. Tomos I y II. Pablo Guadarrama (dir.) La Habana: Félix Varela.

Colectivo de autores. (2002). Pensamiento español y latinoamericano contemporáneo. Santa Clara: Editorial Feijoo. Universidad Central Marta Abreu de Las Villas.

Colectivo de autores de la Universidad Central de las Villas. (1995). Guadarrama, P. \& Rojas, M. (dir.). El pensamiento filosófico en Cuba en el siglo XX (1900-1960). México: Universidad Autónoma del Estado de México. (Reedición cubana,1996). La Habana: Félix Varela. (3a. ed., 2003). La Habana: Pueblo y Educación.

Delgado, I. (1986). El pensador cubano Rafael Montoro (1852-1923) y su presencia filosófica en España. IV Seminario de Historia de la Filosofía Española. (Actas). Salamanca.

Días, M. (2001). Ideologías y revolución. Cuba 1959-1962. La Habana: Ciencias Sociales.

Escalona, A. (2003). En torno a los aspectos filosóficos del pensamiento martiano. Universidad de Oriente.

Fabelo, J. (1989). Práctica conocimiento y valoración. La Habana: Ciencias Sociales. 
Fabelo, J. (1996). Retos al pensamiento en una época de tránsito. La Habana: Academia.

Fernández, O. (1988). Formación y desarrollo del estado socialista en Cuba. La Habana: Ciencias Sociales.

Fornet-Betancourt, R. (1994). José Martí y la filosofía. En José Martí 1895-1995. Literatura-política-filosofía-estética. Universitát Erlangen-Nürnberg. Lateinamerika-Studien 34. Frankfurt am Main: Vervuert Verlag.

Fung, T. (1982). En torno a las regularidades y particularidades de la revolución socialista en Cuba. La Habana: Ciencias Sociales.

García, G. (1979). Algunas conferencias de filosofía. La Habana: Editora Política.

García, G. (1984). Categorías del materialismo dialéctico. La Habana: Editorial Gente Nueva.

García, G. (1982). Filosofía, ciencia e ideología. Cómo la filosofía se hace ciencia con el marxismo. La Habana: Científicotécnica.

García, R. (1943). Esquema de un correlato antropológico en la jerarquía de los valores. La Habana. (S. e.)

García, R. (1956). Redescubrimiento de Dios. Una filosofía de la religión. La Habana: Lex.

García, X. \& Cano, L. (1994). El posmodernismo esa fachada de vidrio. La Habana: Ciencias Sociales.

Gerstenberg, B. (1985, septiembre-diciembre). El inicio de la ilustración filosófica cubana: José Agustín Caballero. En: Islas, 82. Santa Clara: Universidad Central Marta Abreu de Las Villas.
Gerstenberg, B. (1986). Grundzüge der philosophischen Aufklärung in Kuba. Eine Untersuchung am Beispiel des philosophischen Werkes von José de la Luz y Caballero. (Tesis doctoral). Universidad de Rostock.

Gómez, C. (S. f.). Carlos Baliño. La Habana: Ciencias Sociales.

Gómez, R. (1989). Influencia del krausismo en Cuba. En: El krausismo y su influencia en América Latina. Fundación Friedrich Ebert. Salamanca: Instituto Fe y Secularidad.

González, F. (1914). Moral religiosa y moral laica. Enrique José Varona (prólogo). La Habana: Cuba Contemporánea.

Guadarrama, P. (1979). El positivismo de Manuel Sanguily. En: Islas. Revista de la Universidad Central Marta Abreu de Las Villas. 64.

Guadarrama, P. (1979). La huella del positivismo en la obra de Fernando Ortiz. En Islas, 70. Revista de la Universidad Central Marta Abreu de Las Villas.

Guadarrama, P. (1980). El papel de Enrique Piñeiro en la introducción del positivismo en Cuba. En: Islas, 65. Revista de la Universidad Central Marta Abreu de Las Villas.

Guadarrama, P. (1981). Die philosophische Aufassung Enrique José Varonas uber die gesellschafltiche Entwicklung. En: Referateblatt Philosophie. Reihe E. Berlín, 17, 2, B 1.15 (204).

Guadarrama, P. (1981). La influencia del positivismo en Emilio Bobadilla. (Coautor Omar George). En: Islas, 68. Revista de la Universidad Central Marta Abreu de Las Villas. 
Guadarrama, P. (1982). El positivismo comtiano de Andrés Poey. En: Islas, 72. Revista de la Universidad Central Marta Abreu de Las Villas.

Guadarrama, P. (1985). Valoraciones sobre el pensamiento filosófico cubano y latinoamericano. La Habana: Editora Política.

Guadarrama, P. (1988). Tendencias en la recepción del marxismo en el pensamiento filosófico cubano. En: Dialéctica, 18. a. XI. (Puebla. 1986). Revista Cubana de Ciencias Sociales. La Habana.

Guadarrama, P. (1990). Marxismo y antimarxismo en América Latina. Bogotá: Universidad INCCA de Colombia. (2a. reimpresión, s. f.). México: El Caballito. (3a. reimpresión, 1994). La Habana: Editora Política. (4a. reimpresión, 1994). México D.F.: (S. e.).

Guadarrama, P. (1994). Postmodernismo $y$ crisis del marxismo. México D.F.: Universidad Autónoma del Estado de México.

Guadarrama, P. (1996). La filosofía en Las Antillas bajo la dominación española. En La filosofía en la América Colonial. Marquínez, G. y Beuchot (coord.). Bogotá: El Búho.

Guadarrama, P. (1998). ¿Cuba?, ¿marxismo occidental o marxismo soviético? En: Guadarrama, P. Humanismo, marxismo y posmodernidad. La Habana: Ciencias Sociales.

Guadarrama, P. (1998). ¿Para qué filosofar? (Funciones de la filosofía). En: Revista de filosofía, 30. Centro de Estudios Filosóficos Adolfo García Díaz. Universidad del Zulia. Maracaibo. Reproducido en Filosofía y Sociedad, Tomos I y II. (2000, 2001, 2002). Pablo Guadarrama (dir.). La Habana: Félix Varela.
Guadarrama, P. (1998). Humanismo, marxismo y posmodernidad. La Habana: Ciencias Sociales.

Guadarrama, P. (2001). Positivismo en América Latina. Bogotá: Universidad Nacional Abierta a Distancia.

Guadarrama, P. (2001). Humanismo en el pensamiento latinoamericano. La Habana: Ciencias Sociales. (2a. reimpresión, 2002). Tunja: Universidad Pedagógica y Tecnológica de Colombia.

Guadarrama, P. (2003). José Martí y el humanismo latinoamericano. Bogotá: Convenio Andrés Bello.

Guadarrama, P. (2004). Positivismo en América Latina. La Habana: Ciencias Sociales.

Guadarrama, P. \& Pereliguin, N. (1988). Lo universal y lo específico en la cultura. Bogotá: Universidad INCCA de Colombia. (2a. reimpresión, 1989). La Habana: Editora de Ciencias Sociales. (3a. Reimpresión, 1998). Bogotá: Universidad INCCA de Colombia.

Guadarrama, P. \& Tussel, E. (1986). El pensamiento filosófico de Enrique José Varona. La Habana: Ciencias Sociales.

Ibarra, J. (2004). Varela, el precursor. Un estudio de época. La Habana: Ciencias Sociales.

Jardines, A. (2004). El cuerpo y lo otro. Introducción a una teoría general de la cultura. La Habana: Ciencias Sociales.

Jardines, A. \& González, J. (1990). Reflexiones en torno al espiritualismo de José Martí. La Habana: Ciencias Sociales.

Lamar, A. (1922). Las rutas paralelas. La Habana: Imprenta El Fígaro. 
Lamar, A. (1927). Biología de la democracia. La Habana: Minerva.

Limia, M. (2001). Derechos humanos. La Habana: Editora Política.

Lles, F. (1924). La escudilla de Diógenes. La Habana: Nueva Novela.

Lles, F. (1923). La sombra de Heraclito. La Habana. (s. e.).

Lles, F. (1934). El individuo, la sociedad y el Estado. La Habana: Editorial Cultural.

Luz \& Caballero, J. (1946). La polémica filosófica. Cuestión de Método. La Habana: Universidad de la Habana.

Luz y Caballero, J. (1981). Selección de textos. Sánchez de Bustamante \& Montoso (selección y prólogo). La Habana: Ciencias Sociales.

Mañach, J. (1951). Para una filosofía de la vida y otros ensayos. La Habana: Le.

Martí, J. (1975). Obras Completas. Tomo XIX. La Habana: Ciencias Sociales.

Martí, J. (1988). Socialismo, trabajo y juventud. La Habana: Ciencias Sociales.

Martínez, A. (1990). Las ideas filosóficas de José Martí. La Habana: Ciencias Sociales.

Martínez, F. (1988). Desafíos del socialismo cubano. La Habana: Centro de Estudios sobre América.

Martínez, M. (1987). La enseñanza problémica de la filosofia marxista-leninista. La Habana: Ciencias Sociales.

Mateo, J. (1986). Tipos históricos de unidad del conocimiento científico. La Habana: Ciencias Sociales.
Memorias del Coloquio Internacional de La Habana. La Habana: Imagen Contemporánea (1999). Félix Varela. Ética y anticipación del pensamiento de la emancipación cubana.

Menocal, R. (1947). Origen y desarrollo del pensamiento cuban, Tomo II.. La Habana: Lex.

Mestre, J. (S. f.). De la filosofía en La Habana. Publicaciones del Ministerio de Educación. La Habana: Dirección de Cultura.

Miranda, O. (1989). Ecos de la Revolución Francesa en Cuba. La Habana: Ciencias Sociales.

Miranda, O. (1984). Félix Varela, su pensamiento político y su época. La Habana: Ciencias Sociales.

Monal, I. (1985). Las ideas en América Latina. Tomo I y II. La Habana: Casa de Las Américas.

Monal, I. (1974). Tres filósofos del centenario. En Cuatro intentos interpretativos. $\mathrm{La}$ Habana: Pueblo y Educación.

Monal, I. \& Miranda, O. (1994). Filosofía e ideología en Cuba. (Siglo XIX). México: UNAM.

Monal, I. \& Miranda, O. (Selección e introducción) (2002). Pensamiento cubano. Siglo XIX. La Habana: Ciencias Sociales.

Montero, G. et. ál. (1987). La educación estética del hombre nuevo. La Habana: Ciencias Sociales.

Montori, A. (1920). Influencia de las ideas filosóficas en la educación. La Habana: Imprenta Cuba Pedagógica. 
Montori, A. (1914). La enseñanza religiosa y la moral cristiana. La Habana: Imprenta Cuba Pedagógica.

Montoro, R. (1930). Obras. Tomo I-III. La Habana: Editorial Cultural.

Nicola, J. (1968). Introducción a la lógica moderna. Tomo I y II. La Habana: Instituto del Libro.

Núñez, J. (1987). Interpretación teórica de la ciencia. La Habana: Ciencias Sociales.

Núñez, J. (1987). Ensayos sobre filosofía, teoría e historia de la ciencia. Camaguey: Universidad de Camaguey.

Perojo, J. (2003). Artículos filosóficos y politicos de José del Perojo (1875-1908). Madrid: Universidad Autónoma de Madrid.

Piñera, H. (1952). Filosofía de la vida y filosofia existencial. La Habana: Publicaciones de la Sociedad Cubana de Filosofía.

Piñera, H. (1952, enero-junio). La filosofía de Don Rafael Montoro. En: Revista Cubana de filosofía, 10. La Habana.

Piñera, H. (1954). Introducción a la filosofía. La Habana: Editorial Cultural.

Plá León, R. (1994). Una lógica para pensar la liberación. La Habana: Ciencias Sociales.

Pruna, P. (1991). Los jesuitas en Cuba hasta 1767. La Habana: Ciencias Sociales.

Pupo, R. (1986). La práctica y la filosofía marxista. La Habana: Ciencias Sociales.

Pupo, R. (1990). La actividad como categoría filosófica. La Habana: Ciencias Sociales.

Ravelo, P. (1996). El debate de lo modernoposmoderno. La Habana: Ciencias Sociales.
Ravelo, P. (2003). La filosofía en la era del capitalismo mundial. La Habana: Ciencias Sociales.

Rensoli, L. (S/f). Historia de las ciencias e historia de la filosofia. La Habana: Pueblo y Educación.

Rensoli, L. (1988). El positivismo en Argentina. La Habana: Universidad de La Habana.

Rensoli, L. (1987). Quimera y realidad de la razón. El racionalismo del siglo XVII. La Habana: Ciencias Sociales.

Reyes, E. (1989). Félix Varela. 1788-1853. La Habana: Editora Política.

Rivero, D. \& Rojas, I. (1987). Justo Sierra y el positivismo en México. La Habana: Ciencias Sociales.

Rodríguez, C. (1983). Letra con filo. Tomo I. La Habana: Ciencias Sociales.

Rodríguez, C. (1984). José de la Luz y Caballero. En: Revista Cubana de Ciencias Sociales, 5. La Habana.

Rodríguez, C. (1987). Letra con filo. La Habana: UNION. Tomo III.

Rodríguez, C. (1997). Tradición y universalidad. La Habana: Ciencias Sociales.

Rodríguez, T. (1995). José M. y la filosofía española. En: Concordia, 27. Aachen.

Rodríguez, Z. (1983). Conferencias de lógica dialéctica. La Habana: Universidad de La Habana.

Rodríguez, Z. (1984). El problema de la naturaleza especifica del conocimiento filosófico. La Habana: Ministerio de Educación Superior. 
Rodríguez, Z. (1985). Filosofía, ciencia y valor. La Habana: Ciencias Sociales.

Rodríguez, Z. (1988). Obras. La Habana: Ciencias Sociales.

Rojas, M. (1996). El naturalismo ateísta de Fernando LLes. En: Colectivo de autores de la Universidad Central de la Villas. Guadarrama, P. \& Rojas, M. (dirección). El pensamiento filosófico en Cuba en el siglo XX (1900-1960). La Habana: Félix Varela.

Rojas, M. (1994). Mariátegui, la contemporaneidad y América Latina. Universidad INCCA de Colombia.

Ronda, A. (1983). Acerca de la filiación filosófica de José Martí. Anuario del Centro de Estudios Martianos, 6.

Rosa, G. de la. (1984). El libre pensamiento en la segunda mitad del siglo XIX en Cuba. En: Revista Cubana de Ciencias Sociales, 6. La Habana.

Sánchez, F. (1988). ¿Es ciencia la filosofía? La Habana: Editora Política.

Santana, J. (1982). ¿Quién fue...? Félix Varela. La Habana: UNION.

Sánchez de Bustamante \& Montoro, A. (1981). Introducción a de la Luz y Caba1lero. En: Selección de textos. La Habana: Ciencias Sociales.

Sánchez de Bustamante \& Montoro, A. (1984). La filosofía clásica alemana en Cuba. (1841-1898). La Habana: Ciencias Sociales.

Santos, O. (1988). El existencialismo de Nicola Abbagnano. La Habana: Ciencias Sociales.
Fung, T. (dir.). (1999). Jornadas sobre la filosofía y cultura griega. La Habana: Ciencias Sociales.

Sardoya, R. (2000). La filosofía burguesa posclásica. La Habana: Félix Varela.

Serpa, G. (1983). Apuntes sobre la filosofía de Félix Varela. La Habana: Ciencias Sociales.

Simón, N. (1912). Ni Dios, ni almas. La Habana: Imprenta El Libre Pensamiento.

Suárez, G. (S. f.). Introducción a la especialidad de filosofía marxista-leninista. La Habana: Universidad de La Habana. Ediciones ENSPES.

Ternevoi, O. (1981). La Filosofía en Cuba. 1790-1878. La Habana: Ciencias Sociales.

Torres-Cuevas, E. (1995). Felix Varela, los orígenes de la ciencia y con-ciencia cubanas. La Habana: Ciencias Sociales.

Ubieta, E. (1993). Ensayos de Identidad. La Habana: Ciencias Sociales.

Fernández, L. \& Fernández, A. (1974). Eolítica y estética en la época moderna. $\mathrm{La}$ Habana: Ciencias Sociales.

Ulloa, H. \& Chacón, N. (1988). Educación moral. La Habana: Ciencias Sociales.

Varela, F. (1961). Lecciones de filosofía. La Habana: Universidad de La Habana.

Varona, E. (1880). Conferencias filosóficas. La Habana: Lógica. Miguel de Villa.

Varona, E. (1906). Discurso en Universidad de La Habana. En: Revista de la Facultad de Filosofia y Letras. La Habana: Universidad de La Habana. 
Varona, E. (1918). Por Cuba. La Habana: Imprenta Siglo XX.

Varona, E. (1902). Nociones de lógica. La Habana: Imprenta. La Moderna Poesía.
Vitier, M. (1970/2004). Las ideas y la filosofía en Cuba. La Habana: Ciencias Sociales.

Zea, L. (1965). El pensamiento latinoamericano. México D.F.: Pormaca. 